Portland State University

PDXScholar

4-1-1969

\title{
Some interrelationships between a community work and training program and selected indices of family functioning
}

Audrey K. Arnst

Portland State University

Laszlo Dezsofi

James R. Friesen

Gary P. Heer

Bennett Holt

See next page for additional authors

Follow this and additional works at: https://pdxscholar.library.pdx.edu/open_access_etds Let us know how access to this document benefits you.

\section{Recommended Citation}

Arnst, Audrey K.; Dezsofi, Laszlo; Friesen, James R.; Heer, Gary P.; Holt, Bennett; Linkous, Courtney L.; and Watson, Edna S., "Some interrelationships between a community work and training program and selected indices of family functioning" (1969). Dissertations and Theses. Paper 906.

https://doi.org/10.15760/etd.906

This Thesis is brought to you for free and open access. It has been accepted for inclusion in Dissertations and Theses by an authorized administrator of PDXScholar. Please contact us if we can make this document more accessible: pdxscholar@pdx.edu. 


\section{Author}

Audrey K. Arnst, Laszlo Dezsofi, James R. Friesen, Gary P. Heer, Bennett Holt, Courtney L. Linkous, and Edna S. Watson 
AN ABSTRACT OF THE GROUP PROJECT OF Audrey K. Arnst, Laszlo Dezsofi, James R. Friesen, Gary P. Heer, Bennett Holt, Courtney L. Linkous and Edna S. Watson for the Master of Social Work presented April 15, 1969.

Title: Some Interrelationships Between a Community Work and Training Program and Selected Indices of Family Functioning.

\section{APPROVED BY MEMBERS OF THE GROUP PROJECT COMMITTEE:}

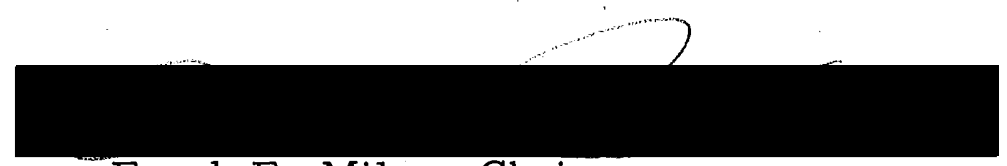

Frank F. Miles, Chairman

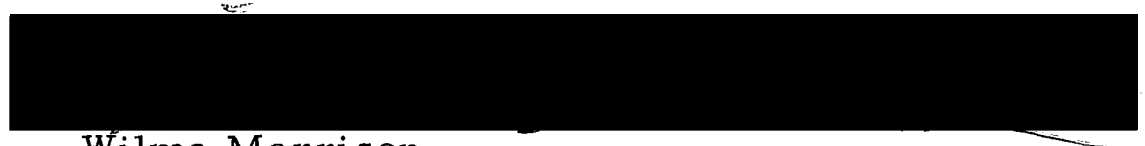

Wilma Morrison

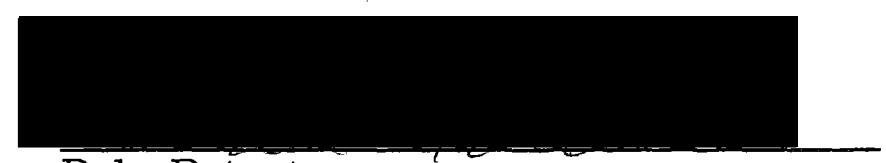

Dale Poteet

This was an exploratory study of some of the relationships between a Community Work and Training. Program and the family functioning of certain participants in that program. The CWT projects studied were those operated by the Public Welfare Departments of Clackamas and Marion Counties, Oregon during the three-year span between January 1, 1965 and December 31, 1967. 
Participants' names were randomly selected from the records of the two welfare offices and the respondents interviewed during the summer of 1.968. A questionnaire was developed which consisted of twenty primarily open-ended questions and this was administered to a total of sixty couples. The questions focused on changes in parental, child, financial, marital and social functioning which occurred during the time the husband participated in the work training project. To identify these changes a list was drawn up of fourteen indices of family functioning and these indices were later categorized under two general headings, external and internal to the family.

The basic hypothesis was that the CWT Program contributed to positive family functioning. This was expanded into a guiding hypothesis which stated that family functioning is improved through participation in the CWT Program and that this improvement is associated with the program, work itself and the social work services provided by the welfare departments. To determine the validity of these hypotheses a number of null hypotheses were then advanced and tested.

The findings of the study were as follows. Internal family functioning was improved during participation on CWT and this improvement affected the total family unit. External functioning, however, deteriorated and this was attributed to the reduced income resulting from the families' dependence for support upon Public 
Welfare. The improved internal functioning was associated with the social work services provided and with the work itself. This improvement was evident despite the reported failure of the program to meet the two most important expectations of the participants, namely material benefits and vocational training.

The most important limitations noted in the research were two. The first was the lapse of time which occurred between the interviews and the period when many of the participants actually worked on the program. Inevitably, such lapse of time had some effect on respondents' recall. Second in importance in considering the possible application of the findings was the fact that some $15.58 \%$ of the respondents from Marion County were Spanish-Americans. This minority group would conceivably not be representative of another area.

Among the program's negative features mentioned by participants were the lack of choice available in job assignment and the inadequate compensation for performance on the job. Despite these, however, the overall conclusion reached by the research group was that participants in the CWT projects saw the program as beneficial in helping to maintain family life. 
SOME INTERRELATIONSHIPS BETWEEN A COMMUNITY WORK

AND TRAINING PROGRAM AND SELECTED

INDICES OF FAMILY FUNCTIONING

by

AUDREY K. ARNST

LASZLO DEZSOFI

JAMES R. FRIESEN

GARY P. HEER

BENNETT HOLT

COURTNEY L. LINKOUS

EDNA S. WATSON

A group project submitted in partial fulfillment of the requirements for the degree of

MASTER OF SOCIAL WORK

Portland State University

1969 
TO THE OFFICE OF GRADUATE STUDIES:

The members of the Committee approve the group project of Audrey K. Arnst, Laszlo Dezsofi, James R. Friesen, Gary P. Heer, Bennett Holt, Courtney L. Linkous and Edna S. Watson presented April 15, 1969.

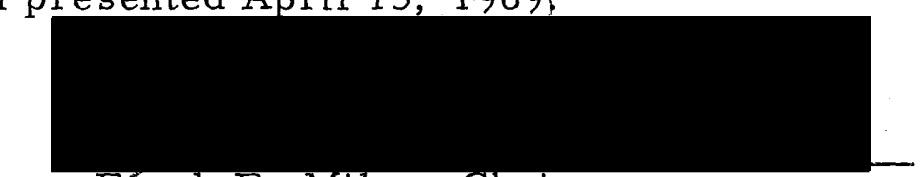

Frank F. Miles, Chairman

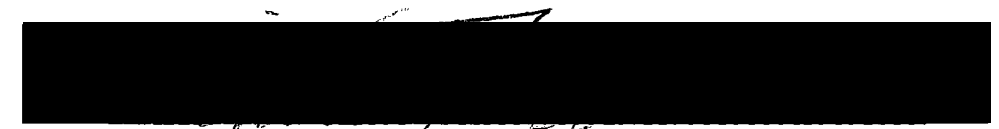

Wilma Morrison

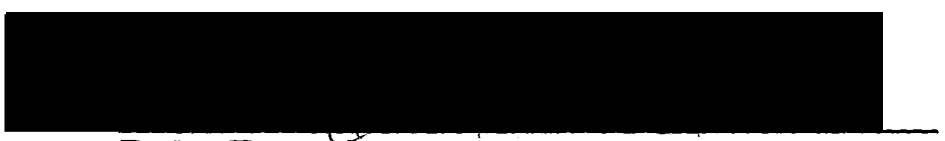

Dale Poteet

APPROVED:

Daniel E. Jelhings, Acting Dean, School of Social Work

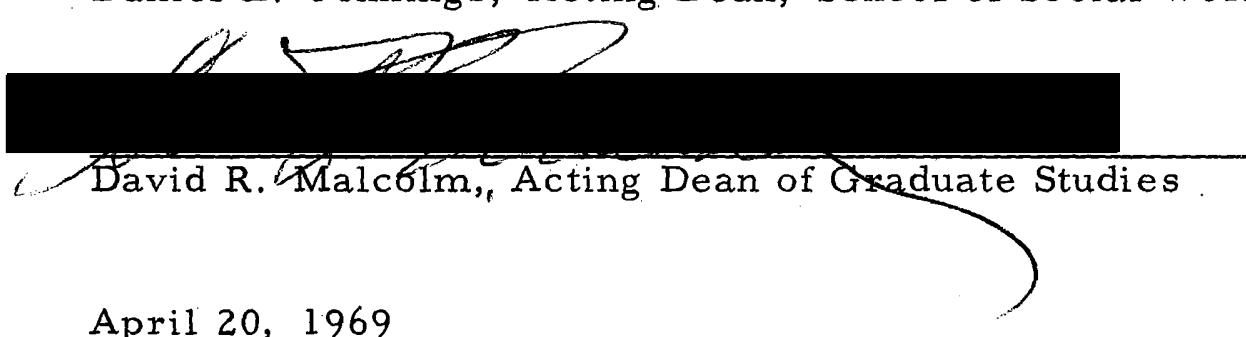

April 20, 1969 
TABLE OF CONTENTS

PAGE

LIST OF TABLES . . . . . . . . . . . . .

CHAPTER

I

INTRODUCTION ...........

The Work Concept from Ancient to Modern Times......... .

Effects of This Work Philosophy on

Those Without Work ...... .

Development of Work Relief . . . . .

II THE APPROACH ............

Organization of Work ...... .

Use of Open-Ended Questions . . . .

Stages of the Study . . . . . . .

Exploration of the Problem . . . . .

Basic Hypothesis. . . . . . . .

Definition of Terms ........

Construction of the Questionnaire and Administration of the Pre-Tests .

The Population . . . . . . . . . .

Sampling Method - Clackamas County . 
Sampling Method - Marion County . .

Data Collection ...........

Data Compilation . . . . . . .

Analysis, Interpretation and Testing of the Data. . . . . . . . .

General Findings: Tests of

Hypotheses..........

Tabular Generalizations . . . . .

Implications . . . . . . . .

Limitations . . . . . . . . .

Summary ........... . .

A SELECTED BIBLIOGRAPHY . . . . . . . . . 


\section{LIST OF TABLES}

TABLE

PAGE

I Effects of CWT Program on Family Life. . .

II Functioning of Children and Parents . . . .

III Differences Between Changes in Internal and External Family Functioning . . .

IV Helpfulness of Caseworker.........

V Preference as to Frequency of Casework

Contact . . . . . . . . . . . .

VI The Number of People Experiencing

Satisfaction with the Program by

Categories .............

VII The Number of People Experiencing Dis satisfaction with the Program by Categories ............

VIII Attitudes Toward the Program........

IX Participants' Expectations of the Program. .

X Fulfillment of Participants' Expectations . .

XI Realization of Expectations......... 
XII Changes in Level of Living During Participation . . . . . . . . .

XIII Spending Pattern Before and After

Participation ...........

XIV Modal Response Categories Indicating

Differences in Reaction to Program, by Counties ........... . 


\section{CHAPTER I}

\section{INTRODUCTION}

This is the report of a study of some effects of a work relief program on the family functioning of sixty families in Clackamas and Marion Counties, Oregon. The principal objectives were: (1) to assess the impact of the work project on families, (2) to study factors associated with changes in family functioning, and (3) to evaluate the importance of providing casework services to the participants and their families.

Community Work and Training was the title given by the Economic Opportunity Act of 1964 to the particular work relief program which was the subject of this study. The feature of Community Work and Training which made it a work relief program was the requirement that the able bodied participate in a work assignment in order to be eligible for public assistance. This work requirement has been an integral part of public welfare philosophy and, as such, reflects the value placed upon work by the society at large, This value is summarized in the preface to Man in a World at Work: $(5, p, x i)$ 
Work is the social act around which each of us organizes much of his daily waking experience and, hopefully, establishes a meaningful and rewarding life routine. One has but to witness the lives of men without work, or of men who lack edifying work - alienated, thwarted, and cut off from the fulfillment of the most human of sentiments, a sense of usefulness and purpose - to recognize the validity of the commonly voiced doctrine that work is, indeed, a way of life.

Work, however, has not always been so highly valued and the stages through which this concept of work developed are part of the history and philosophy of present-day work relief.

\section{THE WORK CONCEPT FROM ANCIENT TO MODERN TIMES}

In classical Greece and Rome work was seen as a curse.

Wrenn (33, p. 25) reminds us that the Greeks used the same root word for both work and sorrow and thus reflected their belief that the gods condemned man to work out of hatred for him. In both Greece and Rome slavery as an institution developed to relieve citizens of this curse of work. Ancient Hebrews saw it as "dismal drudgery" man was obliged to suffer as punishment for original sin. (31, p. 126) Even early Christianity seems to Wilensky (31, p. 126) to have discouraged work, seeing it as a diversion from service to God. It was not until Catholicism began to reach out for closer ties with the community outside the Church that people began to place a greater value on a life of work. Even then a life of work was considered to have less dignity and status than one of prayer. However, 
by the time of St. Thomas Aquinas (1225 - 1274 A. D. ) there had developed a philosophy regarding the value of work to society which was similar to that of the Catholic church today: "Work is a natural right and duty, the sole legitimate base of society, the foundation of property and profit . . but it is always a means to a higher spiritual end." (31, p. 127)

This changed viewpoint toward work continued until about the time of the Reformation in Western Europe. Then the resulting liberalization of religious thinking developed, among other things, the concept that work was in itself a way of serving God and was an activity necessary to man. At the same time,

. . developments in science, technology and exploration were laying the groundwork for the vast economic expansion of the sixteenth and early seventeenth centuries. Doctrines of work, rooted in the pattern of entrepreneurial opportunities and motivation that emerged with economic growth, found sanction in theology. . . . This is the period in which the "Protestant Ethic", together with other strands of Christian doctrine, meshed with the "Spirit of Capitalism" to form, ultimately, a secular religion of work. (31, p. 127)

Luther, for example, said that work, in addition to being essential, ". . was carrying out God's purpose in one's life." (33, p. 25) Calvin believed that God required men to work. Profit making was included in this provided that the said profits were invested in ventures which would provide more work. The growth of the Protestant Ethic, as Wilensky interprets Max Weber in Man in a Worldat Work (31, p. 128) encouraged ". . ceaseless effort to 
make the earth the mirror of divine majesty" and taught that ". . . it was everyone's duty to seek that work which would bring to him and to society the greatest return." (31, p. 128)

It is this view of work that has been a major influence on Western ideology since then and which was reflected in the various utopias which became popular, especially in the 1800's. As early as 1516 Sir Thomas More had conceived of a world where all men worked and this thread ran through most of the utopian thinking of later centuries. For example, the rule in Saint-Simon's utopia, in which the class system was based on occupation according to a man's natural capacities, was that "all men shall work." (31, p. 129)

In the American frontier days there was probably less tribute paid the religious aspects of the mandate to work because man had to work in order to survive; work was honored directly for its value to society and a man had status based on the product of his work. With the growth of industrialization, however, status was no longer based on the tangible results of one's work but on the kind of work one performed. The emphasis was on occupation. In addition to this, industrialization brought other changes. When the product of man's work resulted directly from the work process itself man had a tangible source of pride in accomplishment. With the advent of modern technology this tangible job satisfaction was often lacking. This loss of the direct reward, in the form of the end product of man's own 
labor, has produced, in the opinion of Herzberg et al., many social ills. (16, p. 124)

These authors point out that while our society has changed drastically, our official ideology continues to stress frontier values. (16, p. 124) Of primary importance in these values is that man work. The direct product, object of pride and symbol of accomplishment, is gone but there remains the "Protestant Ethic" which Wilensky (31, p. 127) says makes of work almost a secular religion. Thus, man's need to work survives and man's occupation continues to be a basic source of identity. Wrenn (33, p. 24) has pointed out that when we ask the question, "who is he?" it usually means "what does he do - - what is his job?" William C. Menninger, in his introduction to Borow's book $(5$, p. xiii) noted, ". . . work determines the way of life, particularly as it applies to the head of a household." And Engel (11, p. 165) says: "It is through a work role that one establishes a position as an effective member of the society. . ."

Establishment of a work role requires that society be aware of a man as a working person. Industrialization does this by making the fact that he works visible, not only to those with whom he works, but also to others who see him going to work. This visibility reinforces work as a primary measure of a person's adequacy in functioning and tends to become blended with that work ethic which equates work with strength of character. 
Even our ideas about leisure have been affected by this work ethic, for leisure is commonly viewed as something for which a man labors, something he must earn. If a man has not worked, therefore, he is not entitled to leisure nor is he psychologically or morally prepared for it. Because of this, one who has not worked and is not working may have free time, but not leisure. (1, p. 79)

\section{EFFECTS OF THIS WORK PHILOSOPHY ON THOSE WITHOUT WORK}

With the value of work so firmly entrenched in our culture the effects of lack of work become easy to understand, Without work the unemployed man may be viewed as lazy and lacking in that beforementioned strength of character which is the hallmark of the employed person. It is this same philosophy that man must work for what he gets that has so influenced the public assistance policy by which recipients are granted bare subsistence. ". . . it would run counter to our system to pay non-contributors more than those who contribute to production. " (26, p. 53)

Feldman and Scherz (13) indicate that the value our society places on work can further be seen in such expressions as a person's being "worth his salt" or "poor but honest."

The continued high value placed on work in today's society is manifest in a variety of ways. The common accolade that a person is "worth his salt" attests to the prevalent regard for the one who earns his way, especially if he "pulled 
himself up by the bootstraps. " This idea of being worth one's salt is not related to the valuable and indispensable one percent suspended in human plasma. It stems from ancient forms of payment for service in salt because other money forms were scarce. In antiquity, salt possessed a religious symbolism closely analogous to that of the early coin metals and was believed to possess magical qualities. We have long tended to forget the original import of being worth one's salt, but we have retained a certain respect for work that yields payment - - in a more modern money form that today is also viewed by many as having magical qualities.

The still-common expression "poor but honest" likewise encompasses value judgments about the place of work in American life. Less than a century ago it still was the popular view that poverty was the natural punishment for idleness; wealth and prosperity were the natural reward for industry and intelligence. (13, p. 16)

Especially do these views apply to men, for the predominant

view of the public is that the man must be the earner and provider in the family. Because his work role is a major source of his identity as husband and provider and seen as the one most vital role through which he can function in society, the man (and through him, his family) is keenly affected by the loss of work. Not only is an indis pensable aspect of his identity gone, the meaningful activity of the work itself is also gone. Towle (27) says that it is not only the idleness but ". . . the frustration in idleness that sets in operation the regressive process through which men break down or become what is commonly termed "pauperized." (27, p. 82)

The unemployed man may also exaggerate the stigma associated with not working so that his self-concept is even poorer than his 
neighbors' and associates' perceptions of him. This further depresses his functioning within and without the family circle. Because of this he may isolate himself from community activities which might otherwise help counteract at least some of the destructive effects of unemployment on role fulfillment. $(30$, p. 86) Job loss usually creates problems of both psychological and social adjustment. Other psycho-social effects may include

. . bitterness, lack of confidence, and sagging morale * loses his daily association with his fellow workers. This . . means not only the disappearnace of human relationships . . . but also the end of a meaningful institutional relationship. . . When he is severed from the job.. . he has lost... his institutional base in the economic and social system. $(30$, p. 85$)$

Interviews based on a study of the impact of the shut-down of industrial plants as reported in Unwanted Workers (30) stress the wide range of emotions of the respondents: bewilderment, resentment, anger and fustration. (30, p. 166) The plants covered in this study were four Armour meatpacking plants (in East St. Louis, Illinois; Columbus, Ohio; West Fargo, North Dakota; Oklahoma City, Oklahoma) and a home laundry equipment plant (in East Peoria, Illinois). The emotions reported here, however, could be discerned wherever and whenever such a situation occurs, as is indicated in the 1960 study done in Detroit, Michigan. As reported by Wilensky (31,pp. 133-134) 105 able-bodied white men between 25 and 45 years of age were interviewed. All had been unemployed at least a year 
and were currently on work relief. All were living with their families at the time of interview. The findings included:

. . biographies . . so peppered with layoffs . . . unemployment, and fruitless efforts to obtain work and avoid charity that the chance to earn even bare subsistence... . struck a few of them as the most stable and productive "employment" ever offered to them. . . these men... are extremely isolated . . . Work . . remains a necessary condition for drawing the individual into the mainstream of social life; wherever work ties are severed, there is a decline in community participation and a related sense of isolation. (31, pp. 133-134)

These reactions may be even more intense for the older worker because he often finds that his age, which was an asset when it also represented seniority on the job, is a distinct liability on a competitive job market.

The lack of income, or reduced income, produced by unemployment also, of course, contributes a major portion of the undesirable effects. In the previously-mentioned study of the shut-downs in the meatpacking and laundry equipment plants it was found that spending was reduced not just on luxuries but also on necessities. (30, p. 8l) In addition, as might be expected, the economic insecurity had an effect on other areas of family life and interpersonal relationships. It was because the strain of unemployment is felt so keenly in the family, which is a primary concern of public welfare, that our own study focused on family functioning as it might be af fected by work relief. 


\section{DEVELOPMENT OF WORK RELIEF}

Viewed in the light of a culture which places almost a religious value on work per se it is not strange that society, as it attempted to deal with the problems of the poor, developed work relief as one solution. One of the very early such attempts was recorded in 1526 when Juan Vives of Flanders, considered one of the great thinkers of his day, presented to the governing bodies of the city of Bruges his plan for relief of the poor. Together with advocating registration and investigation of the poor, Vives suggested the creation of employment for them. This, he believed, would effect savings in expenditures for relief. While Vives developed the plan for the city of Bruges he himself later went to England where he and his ideas gained considerable attention. His thinking may well have contributed to the first comprehensive Poor Law enacted by the British Parliament in 1536. Through the process of change and amendment this early act of Parliament evolved into the Elizabethan Poor Law of 1601 . It is this law which the early settlers brought to the New World and which has served as a model for so much of the legislation in the United States.

Administrative features of this law included the following:

(1) local govermental responsibilities for the poor; (2) the classification of those in need, and provision of appropriate kinds of relief for 
each; apprenticeship for children, work for the able-bodied, and almshouses for the incapacitated; (3) financing through taxation; and (4) legally enforced family responsibility. (20, pp. 14-15) These fundamental ideas continued in England until their repeal in 1948.

According to MacIntyre (17) six of the Poor Law principles can be readily discerned in American welfare thought. These include:

(1) public responsibility by local government, in America usually through the town or county rather than the parish; (2) local administration, again by overseers of the poor; (3) financing out of local tax funds; (4) distinctions between the able-bodied poor, who were to be set to work (the Tudor equivalent of work relief and the work test), and the "lame, impotent, old, blind. . ." (shades of our APTD, AB, and OAA programs.! ); and (5) financial responsibility of certain relatives, explicitly set forth in language almost identical to that in many contemporary American statutes. Finally, (6) the Poor Laws limited local financial responsibility to those settled in the parish, and provided for the removal of unsettled poor. (17, p. 9)

In Federal Aid for Relief Williams (32) states that basic relief for the poor was offered under state poor laws through 1929 and this relief was intended to take care of both the able-bodied men and those unfit for employment. (32, pp. 7-8) These poor laws were supplemented by private charity. Prior to 1929 the use of work relief as a form of public assistance was very limited although

- . Practices such as boarding out and auctioning off the poor to the lowest bidders were utilized as a means of providing for the destitute, and of forcing the able-bodied to work for their maintenance. (6, p. 79)

However, there was, during the depression of the $1890^{\prime} s$, an 
early and rather significant use of work relief in this country as an unemployment relief measure which had a s the chief value claimed for it the maintenance of "moral independence." (12, p. 172)

Charnow (6) states that the work relief programs which were in effect in the depressions of the nineteenth century and of the first three decades of the twentieth century were administered locally and financed from local public or private funds. $(6, p, 1)$ Thus, on the eve of the depression of the 1930's, relief in any form was carried out on the local level, and the "responsibility for meeting emergency needs was placed upon the communities, and particularly upon private charity." (8, p. 29) As local funds became exhausted the population began to look to the state and federal governments for aid and there developed increased emphasis upon supplying work for the employable unemployed. There soon were "public works and work relief programs on a previously undreamed-of scale." (17, p. 14) Because this was the era which marked the entrance of the national government into poor relief the programs are historically significant.

One of the earliest of these was The Reconstruction Finance Corporation, authorized in July 1932, "to lend funds to state and local governments for direct and work relief..." (6, p. 1) The first federal program which actually provided jobs for the unem ployed was the Civilian Conservation Crops whose purpose was to provide training and employment for youth through worthwhile 
projects in conservation. In 1933 the federal government established the Federal Emergency Relief Administration through which grants were provided to states and localities for relief purposes. The Public Works Adminstration was also set up in 1933 (June) with the objective of constructing useful public works. The Civil Works Administration was another one established in 1933 but this was liquidated in the following year. The last of these depression programs, by far the largest of the various emergency public aid programs, was the Works Projects Administration. This was approved in April 1935, with the plan to provide work relief to an es timated three and one-half million persons. "Work under the WPA was on socially useful projects; it was not 'made work, ' nor was it long planned public work." (4, p. 37)

In 1942, when the WPA finally ceased its activities, the practice of work relief had practically disappeared and was not revived until the late $1950^{\prime} \mathrm{s}$. At that time the spread of unemployment did cause some communities in the nation, including some counties in Oregon, to again turn to work relief in connection with general as sistance which is totally financed at the local level. (14, p. 191) Then, in 1962, federal welfare amendments allowed the establishment of community work and training programs for unemployed fathers in families receiving public assistance under the Aid to Dependent Children program. This program was partly financed by 
federal funds. Thus, federal funds were again brought into work relief programs although the emphasis of the Department of Health, Education and Welfare was "largely on training rather than on common work projects." (14, p. 191) This federal interest in training the unemployed was not limited to the 1962 amendments however. There were also the Area Redevelopment Act, the Manpower Development and Training Act, and the Work Experience Program of the Economic Opportunity Act.

The first of these, the Area Redevelopment Act which was passed in 1961, provided the first really wide-scale federal retraining program for the unemployed. It

. . authorized assistance to areas with substantial and persistent unemployment both in planning and financing their economic redevelopment and in training their unemployed and underemployed workers. (29, p. 125)

The Manpower Development and Training Act of 1962 called for a

. . diversified nation-wide training program, including on-the-job training, for persons who could not reasonably be expected to find full-time employment without training-with emphasis on family heads, youths between the ages of 19 and 21 , and workers from low-income farm families. (29, p. 125)

Both of these programs were administered by the State Employment Agencies and while the third, the Work Experience Program, also emphasized training rather than only work relief it was administered by the State Welfare Department. This Work 
Experience Program was designed to improve the employment potential of unemployed heads of families and other persons on public assistance who lacked sufficient education or basic work skills for today's job market.

Work Experience was designed to extend the community work and training projects which had begun under the 1962 amendments to the Social Security Act. It was the community work and training program, as it was operated in Clackamas and Marion Counties, upon which this study focused.

The Handbook of Public Assistance Administration (28) sets forth the goals of the program as follows:

\section{1 Purpose}

The basic purpose of section 409 of title IV is to improve the employability of employable or potentially employable relatives caring for children receiving aid to families with dependent children by conserving their work habits and skills, and by developing new skills, through community work and training programs of a constructive nature.

This goal can be accomplished by maintaining and developing good work habits, attitudes, morale and skills through constructive work experience; by acquiring needed education and improved skills through adult education, vocational training and on-the-job experience; and by finding gainful employment through effective job hunting and the special efforts of local public employment offices. (28, sec. 3462.1)

The federal government suggested three types of work projects which could be used in the community work and training program. These were: (1) work projects designed to develop, and to 
prevent deterioration of good work habits, attitudes and morale; (2) community work and training projects designed to improve, or conserve existing skills; and (3) community work and training programs designed to develop new or improved skills through the planned coordination of work experience, training and related instructions. (28, sec. 3462.32$)$

Before the federal government became involved in local welfare, however, some work relief programs were maintained by the states. These were influenced by the same societal value placed upon work which has been previously discussed. A review of the history of poor relief in Oregon, for example, reveals that the poor law passed when the territorial government was established in 1849 , mentions inability to work as a condition of eligibility for receipt of public relief. The law made the provision that each county would be responsible for its own poor but it also prescribed that those who would receive help would be the lame, the blind, the sick or those others who, because of age or infirmity, were unable to support themselves. (22, p. 11) "The law further provided that the probate court in each county should administer this relief in such amounts and at such time, as were necessary." (22, p. 11) The Poor Law of 1854 stated that counties could build workhouses, appoint overseers of the poor or provide care by contract and this law remained the basic poor law of the State of Oregon until 1935. (22, p. 12) 
A Summary of State Laws Relating to the Dependent Classes,

1913 (9) states that in Oregon in 1913 those persons who were entitled to relief were "every poor person, resident in a county, unable to earn a livelihood in consequence of bodily infirmity, idiocy, lunacy, or other cause, who is not supported by relatives, . . ." (9, p. 236)

In Oregon, then, as in most other areas at the beginning of the depression of the $1930^{\prime} \mathrm{s}$, responsibility for relief of the poor was on a local level. In Portland, in November 1930, a Civic Emergency Committee, made up of a body of private citizens, set up city-wide clean-up campaigns to give work to the unemployed. (22, p. 40) Local public works projects were started by the local government in Multnomah County in December 1930. (22, p. 40) A State Emergency Employment Commission was formed in December 1930 to cooperate with the State Highway Commission in a plan to make road work available as relief for some unemployed men in the State. (22, p. 44) It was after these early starts by the state and local governments that the federal programs previously discussed came into existence; examples are FERA, CWA, CCC, PWA.

All during this period in Oregon the general feeling continued that people should be spared the stigma attached to pauper relief. (22, p. 132) To help insure this, the Oregon State Relief Committee and the Federal Emergency Relief Administration both followed the policy that whenever possible the budgetary deficiencies of those on 
relief should be met by cash earned through work rather than by direct relief grants. Thus, according to the Biennial Report of the State Relief Committee to the Governor and Legislative Assembly of Oregon, "Family morale, skill and self-respect are better conserved. . . " (25, p. 17)

As most other states, Oregon did little with work relief during the 1940 's and 1950's, but in 1959 and 1960 a work relief program was initiated as part of the general assistance program. Counties were free to decide if they wanted to operate such a program and both Clackamas and Marion Counties were among the first to do so, Marion County's program was started on December 5, 1960, and Clackamas County's program began on February 1, 1961. Those counties who elected to have a work project had certain uniform operating procedures. Most important among these were two requirements: (1) The employable men who were referred to a work project had "to work a designated number of hours determined by the amount of general assistance for which their families are eligible." (24, p. 7), and (2) persons who, without good cause, failed to report for a work relief project became ineligible for further as sistance. According to the State Public Welfare Commission, assignment to work projects appeared to be "helpful to the recipients in gaining private employment and in improvement of family relationships." (24, p. 7) 
When the 1962 Amendments to the Social Security Act came into effect, Oregon. was well prepared to adapt its work relief project to the community work and training program outlined in the amendments. Oregon was, therefore, one of the first four states to submit plan material to the federal government for this new program. In keeping with the federal objectives, the state program for community work and training was divided into two components of work experience projects and on-the-job training. According to State Public Welfare's staff manual in September 1967, "the intent of work experience projects is to develop employability of a group of welfare recipients by conserving their work habits and/or developing new work habits by participating on projects of a constructive nature." (19, sec. 2417.1) On-the-job training seeks to make an individual employable through providing him with new skills to be acquired through actually performing work on a job. (19, sec. 2417.2) Our respondents for the study were from a group who were participants in the work experience category. To begin with, the programs in Clackamas and Marion Counties were essentially the same, with recipients in both counties working principally in the parks. Then, as the programs expanded, Clackamas County was able to offer work in road construction. Marion County was able to enlarge its program still further by offering, in addition to park and road work, work in the sewage treatment plant and farm labor. 
Such, then, is a brief historical background of work relief. Its development was influenced to a large extent by our culture's philosophy regarding the value of work per se. As a value of society in general this concept of work affects both rich and poor, so that, as previously noted, he who lacks work is often viewed by himself, his associates and the community as lacking in personal worth. As this happens, family functioning deteriorates. The question then arises, does a work relief program mitigate these effects? Both Marion and Clackamas Counties were officially committed to the opinion that work relief does, indeed, help compensate for the lack of employment. No research had been done, however, to substantiate this belief.

This fact, and the growing realization of the need for such research, became the impetus for this study. 
CHAPTER II

\section{THE APPROACH}

Clackamas County Welfare Department pointed out that research concerning the effects of a Community Work and Training Program (CWT) on the family functioning of the participants would be useful, not only to them, but to other counties in Oregon operating similar programs. A tentative proposal was therefore drawn up for the first of a series of studies to explore this area of interest, and a research group was formed in March, 1968.

Four men and three women made up the research group. Four of the members previously had been employed by Departments of State Public Welfare, three in Oregon and one in Alaska. Three had worked in other public social service agencies.

\section{ORGANIZATION OF WORK}

The study originally was planned to be carried out in Clackamas County only. However, one of the early decisions was to broaden the scope to include the CWT Project in Marion County. Marion County officials were enthusiastic and cooperative and the research plans were enlarged to include the two counties. 
Including two county work projects made possible comparisons between contrast groups and the bringing to light of a greater variety of patterns and variables which may become the basis for further study.

The men of the research group were assigned to gather data in Marion County and the three women to Clackamas County. As has been noted, the inclusion of the Marion County CWT Project markedly changed the scope of the study. However, despite being split into two groups working in separate counties, every effort was made to maintain uniformity of method. There were regular weekly group meetings during which questions and problems related to the particular phase of the study under consideration were discussed and resolved. Supplementary meetings of the group were held as needed during the summer and winter vacation periods.

By utilizing group decisions throughout every phase continuity and consistency of approach were maintained and consensus reached on all major decisions. Each group member participated in the formulation of the approach, design, and methodology.

\section{USE OF OPEN-ENDED QUESTIONS}

The choice of the basic approach to this study, which was one of survey rather than experiment, determined the use of many openended questions in the research instrument. Many reasons could be 
cited to support this choice but the most important one was the paucity of information in the literature which dealt with welfare work and training programs. We found very few studies which had been conducted in this area. Because of this it would have been very dif ficult to foresee the conditions and variables which could have been actually controlled and manipulated in an experimental effort. The choice of this approach offered the chance to obtain a maximum amount of information. Inherent in this advantage, however, was the possibility that the data collected would be difficult to handle with inferential statistics. We found this to be true, and much of the data of this study is therefore reported descriptively in the findings. The use of more precise questions utilizing limited response categories, would have produced more manageable data, but would also have resulted in much less information regarding participants' reactions to a welfare work and training program. The spontaneous and often revealing responses of the participants to the open-ended questions suggest many areas which would be profitable for future exploration and study. Obviously, not all of the questions used in the instrument were open-ended, but in those instances where closed questions were used, a number of possible choices were provided and ranged along a continuum. 


\section{STAGES OF THE STUDY}

Using the group approach described earlier, the members progressed through a series of phases in which the research problem was explored, hypotheses formulated, terms defined, research instrument constructed and pre-tested, population defined, sample selected, data collected, and results analyzed and interpreted. Through this sequence of work the study was gradually narrowed down to manageable proportions and completed.

\section{EXPLORATION OF THE PROBLEM}

During this phase we became familiar with the research problem through a review of the literature, meetings with Clackamas and Marion County welfare personnel and orientation to the policies and procedures of each county CWT Program. Because of the limitations of time imposed it was decided to focus on the local CWT Projects only, excluding the formal training programs operated by the county welfare offices in cooperation with the Federal Government.

\section{BASIC HYPOTHESIS}

The result of the exploration of the research problem was the formulation of a basic hypothesis which was stated as follows:

The CWT Program contributes to positive family functioning. 


\section{DEFINITION OF TERMS}

It was then necessary to define what was to be considered positive and negative family functioning. One of the common instruments used by many social agencies to evaluate families who are to receive social services covers the following areas: parental, child, financial, marital, and social functioning. However, the exploratory nature of this study seemed to suggest the need for broader and more detailed criteria and a list of 14 indices of family functioning was therefore developed. These indices were later grouped into two general categories, those considered external to the family and those considered internal to the family. Positive family functioning was defined as behavior which tended to strengthen family life.

VII. CONSTRUCTION OF THE QUESTIONNAIRE AND ADMINISTRATION OF THE PRE-TESTS

With the criteria established the group then proceeded to construct a questionnaire to develop the required information. Lacking results from any previous studies, it was decided to use two pretests, the first to be a pre-test of trial questionnaires developed by each member of the group, and the second to be a pre-test of a standard composite questionnaire constructed by the group as a whole after evaluation of the results obtained from the first pre-test. Both questionnaires were to be administered to both husband and wife 
jointly but with their responses recorded separately. The population for the pre-tests consisted of current participants in the CWT Project in Clackamas and Marion Counties who had been assigned to the program for the first time after January 1, 1968. This population was then excluded from the population used for the actual study. Two interviews were conducted by each member of the research group in both pre-tests and the final standard questionnaire consisted of 20 questions. A copy of the questionnaire is included in the appendix.

The second pre-test gave good indication that the questionnaire would produce the kind of data sought although some minor changes were necessary in the format of the questionnaire in order to facilitate ease in recording responses, Also, the wording of several questions was changed slightly to improve clarity and the final order of questions was set to progress from general questions to more specific ones. This delayed the more penetrating, possibly threatening, specific questions dealing with intrafamily functioning, and allowed the interviewer a little time to establish rapport. It was decided to collect and record all the original basic data on the face sheet of the questionnaire even though not all of it would necessarily be used in the report.

The final format of the questionnaire was thus designed to explore husbands' and wives' perceptions of, and attitudes toward participation on a welfare CWT Project. The questions dealt. with 
expectations, good and bad things about the project itself, problems created by the project for the family, positive and negative effects on family functioning (the 14 indices), feelings regarding the quantity, effectiveness, quality, and necessity of casework services, and overall positive and negative attitudes toward participation in the CWT project.

\section{THE POPULATION}

The tasks of defining the population to be included in the study and drawing the sample in each county were completed during Spring term, 1968. This was done to allow collection of the data during the summer vacation period since it was anticipated that locating the people to be interviewed would be a time-consuming activity. The criteria decided upon for defining the population was that respondents should:

1. Be currently residing in the county of original CWT as signment;

2. Have initially entered and participated in the CWT Program after January 1, 1965, but not after December 31, 1967;

3. Have both parents and at least one child living in the home both currently and at the time of participation in the project;

4. Have been assigned to the work project for at least 30 
consecutive days, and actually work on it, although the number of days worked was to be disregarded.

Although one of the jobs included in the Oregon CWT program was in the Surplus Food Stores the research group decided to eliminate from the population anyone who was not, at least at one time during the three-year time span, eligible for some assignment other than the food store. This was done for three reasons: the job was not representative of the usual CWT assignment, the number of jobs in the food store was so small and the one or two jobs available were reserved for those recipients considered in some way incapacitated for another kind of work.

Some consideration was also given to eliminating members of the Spanish-American minority group because of anticipated language difficulties in an interview. The decision was, however, to include these participants in the population since they do make up a significant minority group in Marion County.

The total population meeting these criteria in Clackamas County amounted to 177 family units. In Marion County the number was 465 , for a total combined population of 642 family units. In the early phases of the study the decision was made to draw a total combined sample of 105 family units; 45 from Clackamas County and 60 from Marion County. This number would have represented $16.35 \%$ of the total combined population of the two counties included in the 
study. However, the difficulty of locating people to interview (due to the mobility of the population) reduced the number of interviews it was possible to complete. In the span of the three years selected for the study many participants had moved, leaving no forwarding addresses which we were able to locate. The result was that only 60 interviews were completed, or $9.35 \%$ of the total population. When broken down by counties this sample represents 22 interviews in Clackamas County or $12.43 \%$ of the population, and 38 interviews or 8. $17 \%$ of the population in Marion County. Although smaller than originally planned, the sample still represents a reasonable proportion of the total combined population.

\section{SAMPLING METHOD - CLACKAMAS COUNTY}

In Clackamas County, a list of all of the men who participated in the CWT Project between January 1, 1965 and December 31, 1967 was taken from monthly attendance records. The 177 names were then put in alphabetical order to eliminate duplications and dice thrown to obtain a chance number. Beginning with that name on the list corresponding to the chance number every tenth name was selected until a sample of 45 had been drawn. These 45 case rjecords were then read by the researchers and evaluated for inclusion in the study according to the criteria established. Five names were eliminated in that reading for the following reasons: four had moved out 
of the county and one had never actually been assigned to the work project. The remaining 40 names made up the sample from which the 22 interviews were completed.

\section{SAMPLING METHOD - MARION COUNTY}

The procedure for drawing the sample in Marion County varied slightly from that used in Clackamas County due to the different record keeping system employed by the Marion County CWT staff. Attendence lists were not kept prior to 1966, although files had been kept on all men referred for possible CWT assignment. These amounted to approximately 600 cases which were read and evaluated by the same criteria. A total population of 465 was obtained and arranged in an alphabetical list. The Table of Random Numbers was used to obtain a number. Beginning with that name, every tenth name was selected until a sample of 60 names was drawn. Each researcher was assigned 15 names. When a researcher exhausted his list of 15 first choices he went back to the master list of the total population for Marion County and selected the first name below the person he was unable to interview. If this name also could not be used then the next name above the name of the first choice was used. In this manner the 38 interviews in Marion County were completed. 


\section{DATA COLLECTION}

After the sample for the study had been drawn, each researcher went to the welfare case records to gather the face sheet data for his assigned interview. Since not all of the families to be interviewed were currently receiving public assistance some of the information, including addresses, was no longer applicable or current. The problem of client mobility has already been mentioned and this factor produced one of the more serious problems in data collection. Often many hours were spent in attempting to locate a family for interview only to find it was not possible to do so.

Whether or not complete face sheet information could be obtained from welfare records, it was always double-checked during the interview itself for accuracy and completeness. This procedure also served as a good "ice-breaker," allowing the researcher to begin establishing the rapport which would facilitate spontaneous, honest responses to the questionnaire. That good rapport was established to a very high degree is evident not only in the variety and quality of the responses recorded but also in the fact that only two persons refused to participate in the study once a face-to-face contact was made. All of the researchers commented upon the hospitality shown to them during the interviews, and upon the willingness of the majority of the people to participate freely and easily in 
the interview.

Prior to the first pre-test conducted appointment letters were mailed to prospective respondents explaining the purpose of the study and giving the time and date the researcher would be calling. Frequently the family was then not home when the call was made. Because of this, and because it was difficult to explain the reason for the visit in a letter without making it sound like a forbidding ordeal, the procedure for the second pre-test was changed. The interviewer simply stopped by unannounced, at a time when husband and wife were likely to be home. This procedure was much more successful and it was adopted for use in the actual study.

After calling at the home and explaining the nature of the visit, making sure that the people understood that the researcher was not employed by the welfare department and that all personal information would be handled so as to insure confidentiality, the researcher set about gathering face sheet information. When the interviewer was satisfied that the interviewees had an adequate understanding of the purposes of the study and the importance of their cooperation to its success the questionnaire was administered. Each question was addressed to husband and wife together and the responses of each recorded. If one or the other of the partners failed to respond spontan eously a neutral probe was used such as "What do you think about that, Mrs. B. ?" If there was still no response it was so recorded 
on the questionnaire. The researcher attempted at all times to convey an attitude of interested, neutral acceptance of all responses and avoided the use of any leading probes. The spontaneous responses to open-ended questions were recorded verbatim, if possible, or by utilizing short sentences to convey the meaning. If a question was not understood by the interviewees the researcher attempted to clarify it without changing the meaning and without leading them toward any particular response.

All of the interviews for this study were done during the period June 1, 1968 through October 13, 1968. The CWT Projects in Clackamas and Marion Counties were not in operation during this period because the program is offered only when there is no other work available in the community for the project participants.

\section{DATA COMPILATION}

Beginning with the weekly meetings of the research group in the fall term 1968 the group addressed itself to the task of handling the data collected during the summer and early fall. This was accomplished in four somewhat overlapping but generally distinct phases:

1. Categorization

2. Tabulation

3. Analysis

4. Interpretation 
As in the earlier phases of the study, decisions were made by the group as a whole. As had been anticipated, the use of open-ended questions resulted not only in much information but also in a considerable variety of responses to certain questions. It was therefore necessary to develop categories which would allow for the grouping of similar responses for easier tabulation, analysis, and interpretation. After much consideration and discussion, in which each member examined the responses recorded in the interviews he himself had conducted, the following categories were developed:

Question Number 1

This deals with participants' expectations of the CWT Project. The categories decided upon were:

Material - All responses implying that the participants expected money in the form of a welfare check for work performed on the project, or other material benefits such as the provision of rain clothes or transportation to and from work.

Training - Responses indicating that the participant expected some kind of vocational training experience.

Job - Responses to the effect that the participant did not expect anything more than just a job--something to do while looking for other work.

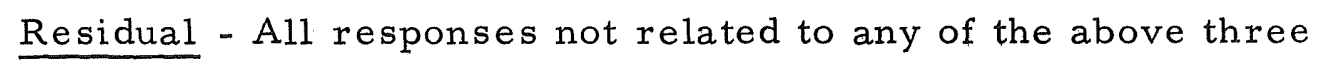


categories. There is little relationship between any of the responses included in this category, and where some similarities do exist, they do not occur with sufficient frequency to justify creating separate categories.

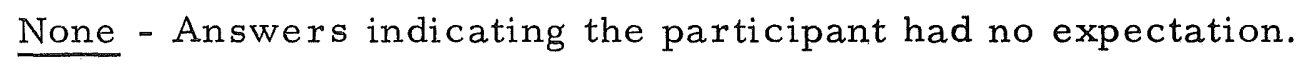
No Response - A complete lack of response--the participant was unable or unwilling to answer.

Questions Number 3-8 and Number 19

These questions deal with positive and negative aspects of the CW T Program as perceived by the participants.

Job Satisfaction - The participant expressed positive or negative reactions in the following areas which are factors of job satisfaction:

1. Earning their own living

2. Working conditions

3. Outdoor work

4. Fellowship with co-workers and supervisors

5. Value to the community of the work done

Material Benefits - Money or other material benefit of lack of same.

Improved or Deteriorated Functioning - Responses indicating improved or deteriorated functioning in the following areas of activity: 
1. Individual.

2. Family

3. Community.

Other - Not related to above categories.

None - CWT Project had no positive or negative aspects of any consequence to the family.

No Response - Unable or unwilling to respond.

Questions Number 12 and 13

These two questions ask for a list of the things for which the participants spent more or less money while working on the CWT Project. The responses fall generally into four categories:

Job Related - Such items as transportation, lunches, and work clothes.

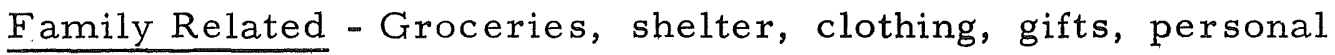
items, and entertainment.

No Difference -

Other -

Question Number $17-\mathrm{C}$

This question asks the respondents to state what kinds of services were offered by the welfare caseworker in connection with the CWT Project. Responses were categorized as follows:

Information - Those responses indicating such help as 
referrals to community resources, advice as to where to look for housing, etc.

Service - Those responses indicating the caseworker helped the participant obtain material things such as stoves, refrigerators, and other household items or services.

Counseling - This category covers responses reporting help given directly by the caseworker in such areas as marital counseling, vocational counseling, and child guidance.

No Help -

Question Number 17-D

Responses to this question were somewhat difficult to handle since it asks with whom the caseworker spends the largest amount, next largest amount, and least amount of time for each of the following: the husband, wife or children.

The possibilities here are so numerous it was decided to limit the categories of response to two, namely with whom does he spend the most time or does he spend his time equally with all.

Question Number 20

Since this question is completely open-ended, responses were categorized under the broad headings of positive, negative, and no response.

After the above-described categories were decided upon, the 
data were tabulated manually in the following manner:

1. Each group member classified the responses in his own completed questionnaires. If there was any doubt about which category a response fitted the question was raised for discussion and resolution at a group meeting.

2. Each member totaled the frequencies under each category for all of his completed questionnaires.

3. Large tabulation sheets were then prepared on which the data for the entire group were combined.

4. Data were classified according to county, and sub-totals for each county then obtained.

5. All frequencies were then totaled, checked and rechecked.

XIII. ANALYSIS, INTERPRETATION AND TESTING OF THE DATA

Following the completion of tabulation the research group addressed itself to the task of analysis. This was carried out by preparing quantitative and qualitative (descriptive) summaries of the findings. These were distributed to each group member for individual study and analysis and this was followed by group discussion in which ideas and implications were thoroughly explored.

The analysis of the data was approached through the formulation of null hypotheses relevant to the basic hypothesis of the study.

On the basis of our original exploration of the research 
problem, as well as group discussions after compilation of the data, we then further hypothesized: the CWT Program, as it had been conducted during the time covered by our study, had more positive than negative effects on family life. The decision was then made to identify and explore the positive and/or negative aspects of the major program components, i.e., work, social service and general program features. These findings we would then associate with either the positive or negative changes in family functioning if such changes were established. This was to be our method of analysis. To recapitulate:

The basic hypothesis was:

The CWT Program Contributes to Positive Family Functioning

A guiding hypothesis for purposes of approach as well as evaluation was then established as follows:

Family functioning is improved through participation in the

CWT Program. The improvement is associated with:
a. The Program
b. Work
c. Social work service

In order to test the validity of our basic and guiding hypotheses, a number of null hypotheses were advanced. These null hypotheses were tested for degree of probability through either the test of the Chi Square distribution or the Test of Proportions, i.e., the 
significance of a percentage and of the difference between two percentages. The nature of the data available after tabulation determined the choice of test. In view of the study's exploratory nature, a confidence level of . 05 appeared reasonable and this level of confidence was used in every test of significance throughout the study.

The collected data were examined as follows for purposes of testing the validity of the null hypotheses:

$\mathrm{H}_{1}-$ Family functioning is improved through participation in the CWT Program.

$\mathrm{Ho}_{1}$ - There is no difference in family functioning before and after participation in the CWT Program.

The most relevant data concerning family functioning before and after participation in the $\mathrm{CWT}$ Program are provided by the tabulated response categories to Question 9. Husbands and wives were asked to rate 14 selected indices of family functioning in terms of no change, deterioration or improvement during participation in the program. The questionnaire provided for five responses. Categories 1 and 2, i.e., "much worse" and "little worse" respectively, as well as categories 4 and 5, i.e., "much better" and "little better" respectively, had been combined into the new categories of "deterioration" and "improvement." This was done for purposes of analysis as well as testing. Findings were derived by observation of frequencies. 
$\mathrm{Ho}_{2}$ - There is no difference in family functioning before and after participation in the CWT Program in respect to either internal or external family functioning.

The relevant data concerning this null hypothesis are also provided by responses to Question 9 of our questionnaire. The five categories of the original rating scale had been combined into three groups consisting of "no change, "improvement" and "deterioration" as described above. The 14 indices of family functioning were then divided into two groups, "internal" and "external"--i.e., to the family--for further analysis of the data. The following indices were considered to be "internal to the family:"

1. Feelings toward the family.

2. Getting along with each other (husbands and wives)

3. Feelings toward work

4. Work habits

5. Getting along with neighbors

6. The children's behavior.

7. The children's grades.

The following indices were considered to be "external to the family:"

1. Housing.

2. Earnings.

3. Food 
4. Things owned.

5. Places gone to.

6. Physical health

7. Church

The apparent differences between improvement and deterioration, when thus related to internal and external family functioning, were tested for significance by the use of the Chi Square test.

$\mathrm{Ho}_{3}$ - There is no difference between the parents' and children!s functioning before and after participation in the CWT Program. Again the relevant data for analysis and testing are provided by the response categories to Question 9. The five categories of responses had been reduced to three, namely "deterioration," "improvement," and "no change."

Two indices, each relating to either the parents' or the children's functioning, were then selected for further analysis. The indices of "getting along with each other" and "feelings toward the family" were treated as indicative of the parents' functioning. The indices of "your children's grades at school" and "your children's behavior" were treated as indicative of the children's functioning. The differences in frequency pattern were tested for significance by the use of the Chi Square test.

$\mathrm{H}_{2}$ - Improvement in family functioning is associated with the CWT Program. 
$\mathrm{Ho}_{1}$ - There is no difference between the families' positive and negative feelings toward the CWT Program.

Relevant data for purposes of testing the validity of this null hypothesis are provided by the responses to Question 20. Families were asked to state both positives and negatives concerning the program. The difference between the positive and negative attitudes-obtained from the frequencies indicated for each category--were tested for significance through the use of the Test of Proportions. $\mathrm{Ho}_{2}$ - There is no significant difference between the participating families' standard of living before and after participation in the C.WT Program.

Data here are the responses to Questions 12 and 13. Essentially, the categories reflected spending patterns, in proportion to available income, before and after participaion. The differences in spending patterns as indicated by the frequencies of responses to these two questions, were tested for significance through the use of the Chi Square distribution. The direction of change in spending patterns was determined by observation of the frequencies.

$\mathrm{H}_{3}$ - Improvement in family functioning is associated with work.

$\mathrm{Ho}_{1}$ - There is no difference between families in respect to program preference: to work or not to work while receiving public assistance.

Relevant data for purposes of testing the validity of this null 
hypothesis were provided by the tabulated responses to Question 18. Families were asked to state their preference for working or not working on CWT while receiving welfare grants. The difference between the three categories of "prefers work, " "prefers not to work," and "qualified and/or ambivalent" was established for observation of tabulated frequencies.

$\mathrm{H}_{4}-$ Improvement in family functioning is as sociated with social work services.

$\mathrm{Ho}_{1}$ - There is no difference between families in respect to positive and negative feelings toward social work service.

Relevant data are provided for the analysis of this null hypothesis by responses to Question 15. Families were asked to rate caseworkers' helpfulness on a scale of five degrees. Categories "rarely/never" and "seldom" were combined into one group of "not helpful" for purposes of testing. Categories "often" and "very often" were combined into one group of "helpful." Category "caseworkers are helpful sometimes" was excluded from the testing process as indicative of an ambivalent response. The difference between the "not helpful" and "helpful" categories was tested for significance through the Test of Proportions.

$\mathrm{Ho}_{2}$ - There is no difference between families in respect to positive and negative feelings concerning the frequency of casework contacts. 
The tabulated frequencies of responses to Question 16 of our questionnaire were examined in the analysis of this null hypothesis. Families were asked to state whether they would prefer to see the caseworker as frequently as they had, less often, or more often. The categories of "not at all" and "less often" were combined for purposes of testing. Significance of differences between those who preferred to see the caseworker less often and those who preferred to see the caseworker more often has been determined by the observation of frequencies.

$\mathrm{H}_{5}$ - There is a significant difference between the husbands' and wives' perceptions of the total program and its effects on family $\underline{\text { life. }}$

Ho - There is no difference between husbands' and wives' perceptions of the total CWT Program and its effects on family life.

The validity of this null-hypothesis was tested by the analysis of every question in the questionnaire. The differences between husbands' and wives' responses to every category within the questionnaire were tested for significance. The Chi Square test was utilized for this purpose.

$\mathrm{H}_{6}-$ There is a significant difference between the families of Clackamas and Marion Counties in respect to perceptions about the total CWT Program. 
Ho - There is no difference between the families of Clackamas and Marion Counties in respect to perceptions about the total CWT Program.

The validity of this null-hypothesis was also tested by analysis of every question in the questionnaire. The differences between the two populations' responses have been tested for significance by the use of the Chi Square test.

In summary, our approach has been one of analytical exploration of attitudes, the identification of positives and negatives as they relate to the program and the family, and the establishment of broad relationships between the positive and negative findings. 


\section{CHAPTER III}

\section{DISCUSSION AND CONCLUSIONS}

The Community Work and Training Programs in Clackamas and Marion Counties had been operating for several years on the basis of a number of assumptions. Among these assumptions, which had served as guidelines for policy-making as well as administration, had been the propostion that participation on CWT had more positive than negative effects on family life. Although these as sumptions had been held since soon after the inception of the CWT Programs in these two counties, no objective evaluation of the above proposed relationship had been done. The research project undertaken by our group substantiated the basic proposition to a significant degree, i.e., that the CWT Program resulted in significantly more positive than negative effects on family life.

This conclusion was arrived at through examination of our findings in relation to the following four major areas of consideration:

1. General findings as related to the tests of hypotheses.

2. Tabular findings related to data which did not lend itself to appropriate statistical manipulation. 
3. Implications of the findings as related to our central hypotheses as well as their practical value in terms of application.

4. Limitations that may have affected our conclusions.

\section{GENERAL FINDINGS: TESTS OF HYPOTHESES}

Our quantitative findings as related to the hypotheses proposed by the research group will be given in the order of the original hypotheses, the null hypotheses and the alternate hypotheses war ranted.

$\mathrm{H}_{1}$ - Family functioning is improved through participation in the CWT Program.

$\mathrm{Ho}_{1}$ - There is no difference in family functioning before and after participation in the CWT Program.

$\underline{\text { Reject }} \quad \underline{\text { By Observation }}$

$\mathrm{Ho}_{2}$ - There is no difference in family functioning before and after participation in the CWT Program with respect to internal and external functioning.

$\underline{\text { Reject }} \quad \underline{P<.001}$

$\mathrm{Ho}_{3}$ - There is no difference between the parents' and the children's functioning before and after participation in the CWT Program.
Accept
$\underline{P}>.20$ 
Improvement in family functioning occurred with an incidence significantly better than chance.

$\mathrm{H}_{2}$ - Improvement in family functioning is associated with the CWT Program.

$\mathrm{Ho}_{1}$ - There is no difference between the families' positive and negative feelings toward the CWT Program.

$\underline{\text { Reject }} \underline{\mathrm{P}<.01}$

$\mathrm{Ho}_{2}$ - There is no difference between the participating families' standard of living before and after participation in the CWT Program.

$$
\underline{\text { Reject }} \underline{\underline{P}<.01}
$$

Although family income decreased in over $50 \%$ of the cases as a result of entering the CWT Program, participating families expressed positive feelings toward the program with an incidence significantly greater than chance.

$\mathrm{H}_{3}$ - Improvement in family functioning is as sociated with the work.

Ho - There is no difference between families in respect to program preference: to work or not to work while receiving public assistance.

\section{$\underline{\text { Reject }} \quad \underline{\text { By Observation }}$}

It is obvious that participating families preferred to work with an incidence significantly greater than chance. 
$\mathrm{H}_{4}$ - Improvement in family functioning is associated with social work services.

$\mathrm{Ho}_{1}$ - There is no difference in families' positive and negative feelings toward social work services.

$\underline{\text { Accept }} \underline{P>05}$

$\mathrm{Ho}_{2}$ - There is no difference between families with respect to positive and negative feelings concerning the frequency of casework contacts.

Accept $\quad$ By Observation

Although $68 \%$ of the frequencies indicated that casework services are helpful and $59 \%$ of the frequencies indicated preference for the present frequency of contacts, no significant differences between positive and negative feelings toward social work services could be established.

Other findings not directly related to the CWT Program's effects on family functioning resulted in the formulation of two general hypotheses. These hypotheses deal with differences in perception according to the sex of the respondents and also according to the county of program participation.

$\mathrm{H}_{5}$ - There is a significant difference between the husbands' and wives' perceptions of the total program and its effects on family life. Ho - There is no difference between husbands' and 
wives' perceptions of the total CWT Program and its effects on farnily life.

\section{$\underline{\text { Reject }}$ \\ By Observation}

In order to test the validity of the null hypothesis relating to $\mathrm{H}_{5}$ we analyzed the response categories of every one of the 20 questions in the questionnaire. The following results were found:

A. No significant differences between husbands' and wives' perceptions were found, by observation, in the following areas:

1. Expectations from the program.

2. Receiving what was expected from the program.

3. Identifying what helped the family most during participation in the CWT Program.

4. The "good things," i. e., positives, of the program.

5. The biggest problems caused by participation in the program.

6. The decrease in available income during participation.

7. The desirable frequency of casework contacts.

B. No significant differences between husbands' and wives' perceptions were found, after a test of significance (Chi Square) in the following areas: 
1. The "three best things," i. e., positives, about the CWT Program.

2. The "three things that are not good,"i, e., negatives, about the program.

3. Positive and negative feelings toward the program; work preference.

C. Significant differences between husbands' and wives' perceptions were found, through the test of Chi Square distribution, in the following areas:

1. Job satisfaction $(\mathrm{P}<.001)$ : this was the most important positive aspect of the program for men.

2. Material benefit $(P<.05)$ : this was the most im portant positive aspect of the program for women.

3. Job satisfaction $(P<.02)$ : this was the most important negative aspect of the program for men.

$\mathrm{H}_{6}$ - There is a significant difference between the families of Clackamas and Marion Counties in respect to perceptions about the total CWT Program.

Ho - There is no difference between the families of Clackamas and Marion Counties in respect to perceptions about the total CWT Program. 
This null hypothesis was tested by contrasting the two populations of Marion and Clackamas Counties in terms of every response category. Husbands' and wives' responses were combined for each county for purposes of analysis. The following results were found:

A. Significant differences between the two counties' populations were established in the following areas:

(Chi Square test used)

1. In expectations concerning the CWT Program $(\mathrm{P}<.001)$.

2. In getting what was expected from the program $(\mathrm{P}<.001)$.

3. Concerning the positive aspects of the program $(\mathrm{P}<.001)$.

4. Concerning the desired frequency of casework contacts $(P<.01)$.

5. Concerning the frequency of home visits $(P<.01)$.

6. Concerning the frequency of office visits (by observation).

7. The amount of casework time spent with husband or wife $(P<.02)$.

8. Positive and negative attitudes concerning the program $(\mathrm{P}<.01)$.

9. Program preference: to work or not to work 
(by observation).

B. No significant differences between the two counties' populations were found in the following areas:

1. Concerning the negative aspects of the program.

2. Concerning the items on which more money was spent during participation.

3. Concerning the items on which less money was spent during participation.

4. Concerning helpfulness of caseworkers.

5. Concerning the view of caseworker's function.

6. Concerning manner of money management.

7. Concerning changes in income during participation.

In addition to the statistical data we found an abundance of other significant quantitative and qualitative data. This information was not handled statistically in this report for two reasons. First, it did not lend itself to appropriate statistical manipulation in view of the project's exploratory nature. Second, it was only indirectly related to the scope and goals of this study. We have, nevertheless, considered this information in our final conclusions, which follow. 


\section{TABULAR GENERALIZATIONS}

1. The CWT Program affected family life and its changes affected the total family unit.

This conclusion is supported by the fact that $31.63 \%$ of the total frequencies of responses to those questions dealing with the effects of the program on family life indicated some change. Table I shows the changes reported in terms of the 14 selected indices of family functioning.

TABLE I

EFFECTS OF CWT PROGRAM ON FAMILY LIFE

\begin{tabular}{lcc}
\hline \hline & $\begin{array}{c}\text { Number of } \\
\text { Frequencies }\end{array}$ & $\begin{array}{c}\% \text { of Total } \\
\text { Frequencies }\end{array}$ \\
\hline No change & 508 & 68.37 \\
Improvement & 111 & 14.93 \\
Deterioration & $\frac{124}{143}$ & $\underline{16.70}$ \\
$\quad$ Total & 743 & 100.00 \\
\hline
\end{tabular}

While a significant proportion of parents improved, effect on children was about balanced between improvement and deterioration, with most experiencing no change. There was no statistically significant association between parents' and children's functioning, taking the group as a whole. These findings are illustrated in Table II. 
TABLE II

FUNCTIONING OF CHILDREN AND PARENTS

\begin{tabular}{lrr}
\hline & Improvement & Deterioration \\
\hline & $23(76.67 \%)$ & $7(23.33 \%)$ \\
Parents' functioning & $9(58.75 \%)$ & $7(41.25 \%)$ \\
\hline
\end{tabular}

2. The direction of change in family life was both positive and negative, and in differing respects.

This conclusion is evident by observation of the frequencies and their proportions as shown in Tables II and III. The information in these tables represents all 14 indices of family functioning examined in this study.

3. The direction of change in terms of either improvement or deterioration was approximately equal in both directions.

This can be seen by further analysis of Table I. Examination of the $31.63 \%$ having shown change gives $47.24 \%$ of frequencies indicating improvement and $52.76 \%$ of the frequencies indicating deterioration.

4. Changes internal to family life were positive.

This conclusion is supported by the analysis of the rejected null hypothesis $\mathrm{Ho}_{2}$ relating to $\mathrm{H}_{1}$. The significant difference 
between internal and external family functioning as related to improvement or deterioration can be seen in the following table.

TABLE III

DIFEERENCES BETWEEN CHANGES IN INTERNAL AND EXTERNAL FAMILY FUNCTIONING

\begin{tabular}{lccccccc}
\hline & \multicolumn{2}{c}{ Deterioration } & \multicolumn{2}{c}{ Improvement } & \multicolumn{2}{c}{ Total } \\
& $\mathrm{N}$ & $\%$ & $\mathrm{~N}$ & $\%$ & $\mathrm{~N}$ & $\%$ \\
\hline Internal & 18 & 21.43 & 66 & 78.57 & 84 & 100.00 \\
External & 101 & 69.65 & 44 & 30.35 & 145 & 100.00 \\
\hline
\end{tabular}

5. Changes external to family life were negative.

This conclusion is again supported by the analysis of the rejected null hypothesis $\mathrm{Ho}_{2}$ relating to $\mathrm{H}_{1}$. This relationship between internal and external family functioning, as related to improvement ox deterioration, is also illustrated in Table III.

6. Positive change in family life was related to social work service.

The null hypothesis was rejected despite a $P>.05<.10$ because the "sometimes helpful" category which was excluded in the testing process may be interpreted more as "helpful" than as "not helpful. " Our conclusion is supported by a careful inspection of the response categories and their proportions. The reasoning is illustrated in the following table. 
TABLE IV

HELPFULNESS OF CASE WORKER

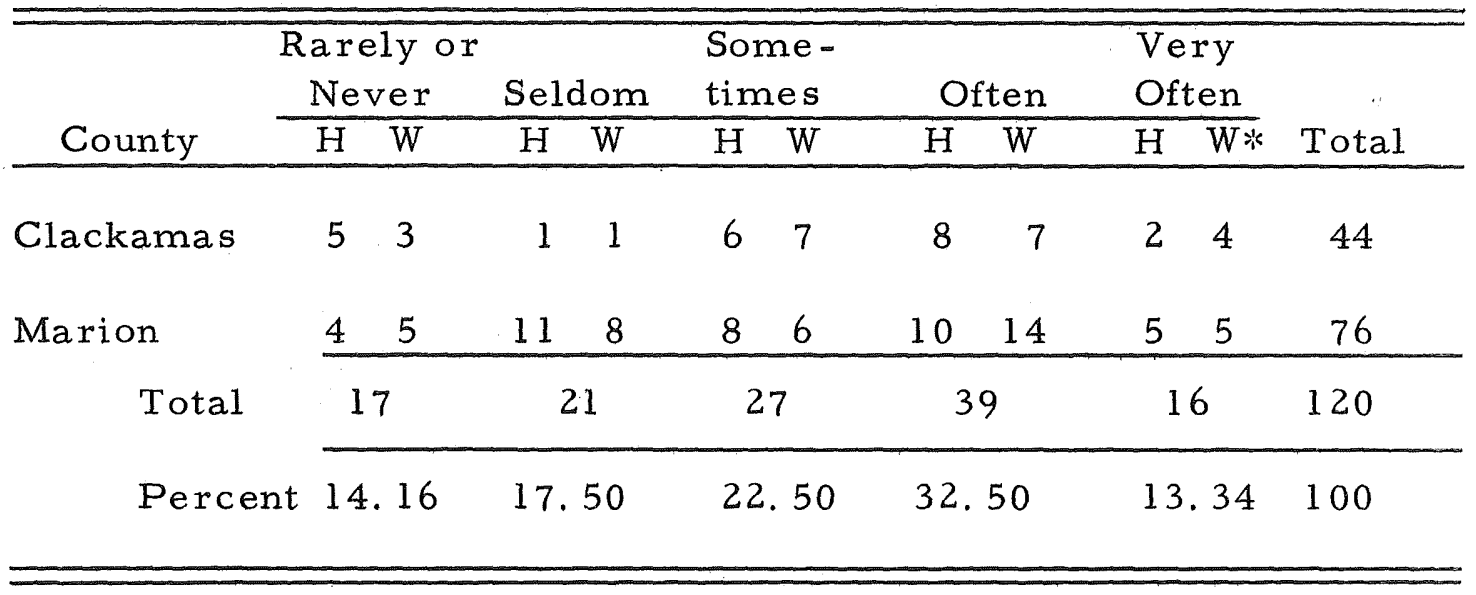

$* \mathrm{H}$ and $\mathrm{W}$ indicate husband and wife.

Interpretation of this "sometimes helpful" category as "helpful" leads to the following conclusions:

(1) Caseworkers are not helpful in $31.66 \%$ of the cases.

(2) Caseworkers are helpful in $68.34 \%$ of the cases.

If the number of frequencies in the "sometimes helpful" category is distributed equally between the "not helpful" and "helpful" then the results are:

(1) Caseworkers are not helpful in $42.91 \%$ of the cases.

(2) Caseworkers are helpful in $57.09 \%$ of the cases.

Another significant finding in the area of the relationship between family functioning and social work service is the conclusion that the present frequency of casework services provided was seen as desirable in approximately $60 \%$ of the cases. However the 
significance of Table $\mathrm{V}$ is that the number of visits was appropriate in more than $40 \%$ of the cases indicating a need for improvement in the basis of determining frequency of casework contacts.

TABLE V

PREFERENCE AS TO FREQUENCY OF CASEWORK CONTACT

\begin{tabular}{|c|c|c|c|c|c|c|c|c|}
\hline \multirow[b]{2}{*}{ County } & $\begin{array}{c}\text { Not at } \\
\text { All }\end{array}$ & \multicolumn{2}{|c|}{$\begin{array}{c}\text { The } \\
\text { Same }\end{array}$} & \multicolumn{2}{|c|}{$\begin{array}{l}\text { Less } \\
\text { Often }\end{array}$} & \multicolumn{2}{|c|}{$\begin{array}{l}\text { More } \\
\text { Often }\end{array}$} & \multirow[b]{2}{*}{ Total } \\
\hline & $\mathrm{H} \mathrm{W}$ & $\mathrm{H}$ & W & $\mathrm{H}$ & $W$ & $\mathrm{H}$ & W* & \\
\hline Clackamas & 0 & 15 & 17 & 1 & 1 & 3 & 3 & 43 \\
\hline Marion & 4 & 20 & 18 & 5 & 6 & 9 & 9 & 75 \\
\hline Total & 11 & \multicolumn{2}{|c|}{70} & \multicolumn{2}{|c|}{13} & \multicolumn{2}{|c|}{24} & 118 \\
\hline Percent & 9.32 & \multicolumn{2}{|c|}{59.32} & \multicolumn{2}{|c|}{11.03} & \multicolumn{2}{|c|}{20.33} & 100 \\
\hline
\end{tabular}

*H and $\mathrm{W}$ indicate husband and wife.

In summary, we draw the following conclusions from the inspection of the categories relating to three clearly distinguished preferences.

(1) Participants who preferred to see the caseworker at the same frequency as they did amount to $59.32 \%$.

(2) Participants who preferred to see the caseworker more often amounted to $20.34 \%$.

(3) Participants who preferred to see the caseworker less often amounted to $20.34 \%$. 
The relationship between social work service and improved family functioning is implied through the examination of the following considerations:

(1) Some $25.89 \%$ of the frequencies expressing positives about the program identified "improved functioning" as a highly significant benefit of participation.

(2) The caseworker's function was defined by the participants and when classified by the research group into categories the following percentages are seen.

(a) The provision of services $-(54.96 \%)$.

(b) Counseling - (22.13\%).

(c) No help - (17.55\%).

We conclude that to be more effective, the planned frequency of contacts by social workers should take into consideration the needs of participants in the program at any one period. Also, there may be a need for better communication of the availability and possibilities for casework beyond providing information and services.

Beyond this it was not possible to conclude how much casework in itself contributed to the improved functioning of families, since the program must be viewed as a whole, in relation to need.

7. Positive change in family life is related to work.

This finding is supported by the rejected null hypotheses 
relating to $\mathrm{H}_{3}$. The analysis was based on the following frequencies relating to work preference.

(1) Prefers assistance with work - 103, equaling $87.30 \%$.

(2) Prefers assistance without work - 9, equaling $7.62 \%$.

(3) Qualified and/or ambivalent - 6, equaling 5. $08 \%$, or a total of 118 , equaling $100 \%$.

In addition to the area of work preference our respondents indicated that work was the most important positive and negative consideration for a person participating in the CWT Program. When asked to identify the positives related to the work program, matters concerned job satisfaction, i. e., earning their own living, working conditions, outdoor work, fellowship with co-workers and supervisors, value to the community of work done, ranked first in importance. When asked to identify the negatives relating to the program, matters concerning job satisfaction were again rated first in importance. (See Tables VI and VII)

However, certain significant differences between the counties and the sexes concerning positive and negative aspects of the program should be noted. An examination of Tables VI and VII reveals that Clackamas County respondents indicated job satisfaction was clearly more important than material benefit or improved functioning. On the other hand Marion County respondents indicated material benefit and improved functioning were almost as important 

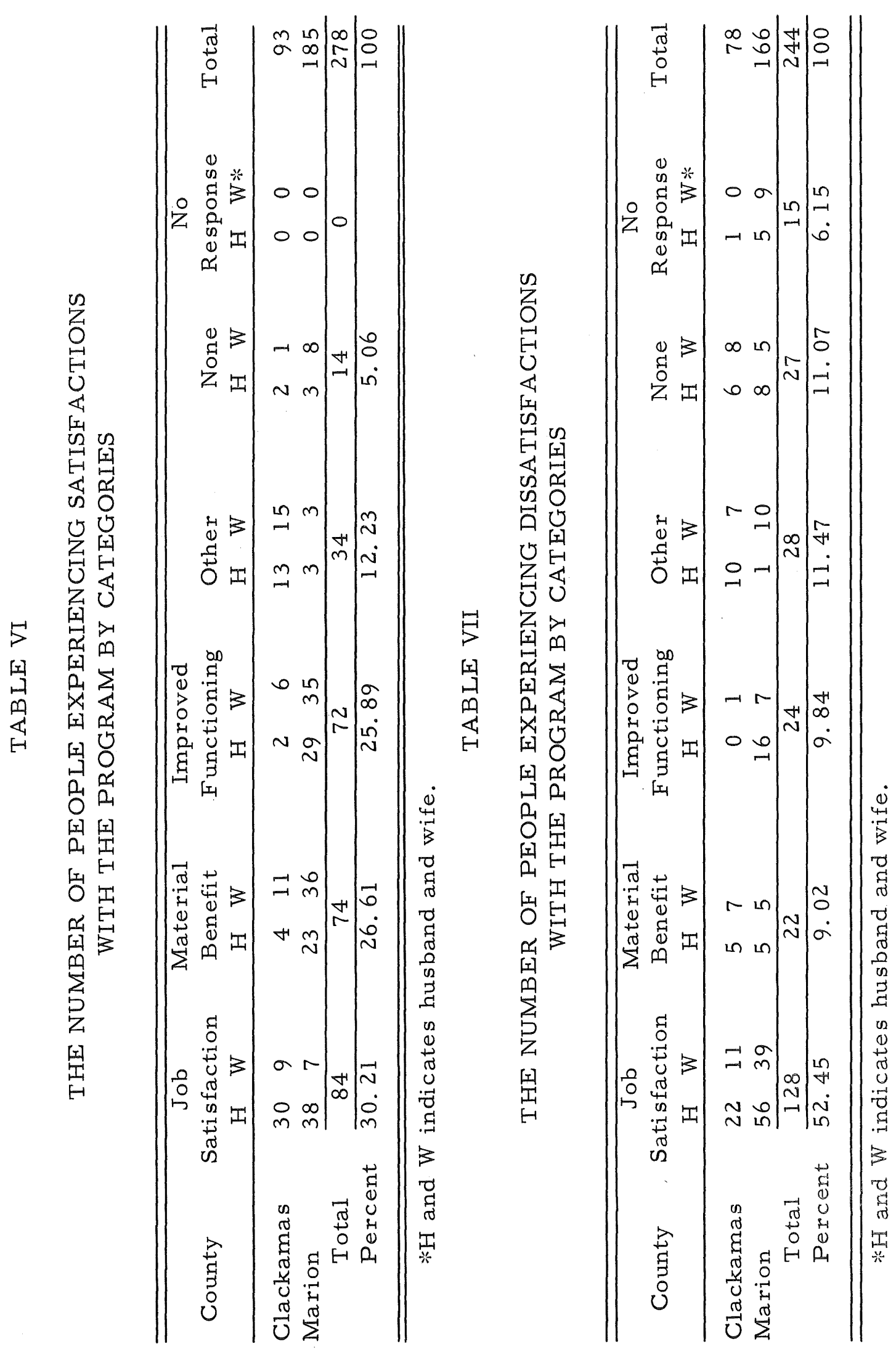
as job satisfaction. In considering differences of responses between sexes of the total population, it is evident that material benefit is the most important positive aspect of the program for wives whereas job satisfaction is the most important aspect for husbands.

Since participants viewed work on the program in positive terms, as evidenced in the data provided concerning work preference, and since they identified positive benefits in terms of job satisfactions, we conclude that the positive aspects of participation on the CWT Program are associated with the positive changes in family life already established. However, although participants overwhelmingly preferred to work for their public assistance, when we compare the "job satisfaction" categories in Tables VI and VII it is evident that more of the respondents rated "job satisfaction" negatively $(52.45 \%)$ than positively $(30.21 \%)$.

8. Positive change in family life is related to attitudes toward the program.

This conclusion is supported by the rejected null hypothesis Ho ${ }_{1}$ relating to $\mathrm{H}_{2}$. The findings are based on the following table. Table VIII clearly illustrates that $48.48 \%$ of the frequencies indicated positive responses to the program. The negative responses consisted of $20.46 \%$ of the total frequencies. Some $31.06 \%$ of the frequencies show no response. It should be emphasized that 
TABLE VIII

ATTITUDES TOWARD THE PROGRAM

\begin{tabular}{|c|c|c|c|c|c|c|c|}
\hline \multirow[b]{3}{*}{ County } & \multicolumn{4}{|c|}{ Categories } & \multirow{2}{*}{\multicolumn{2}{|c|}{ No Response }} & \multirow[b]{3}{*}{ Total } \\
\hline & \multicolumn{2}{|c|}{ Positive } & \multicolumn{2}{|c|}{ Negative } & & & \\
\hline & $\mathrm{H}$ & $\mathrm{W}$ & $\mathrm{H}$ & $\mathrm{W}$ & $\mathrm{H}$ & W* & \\
\hline Clackamas & 9 & 11 & 12 & 5 & 6 & 6 & 49 \\
\hline Marion & 29 & 15 & 9 & 1 & 12 & 17 & 83 \\
\hline Total & & & & & & & 132 \\
\hline Percent & 48. & & 20 & & & & 100 \\
\hline
\end{tabular}

*H and $\mathrm{W}$ indicates husband and wife.

these results were obtained through the use of an open-ended question. Examining the table further we find that the direction of preference is clearly positive. Of those who indicated attitudes in either direction, i.e., if we exclude the "no response" category, $70.40 \%$ responded in a positive manner and $29.60 \%$ felt negatively about the program.

9. Positive changes in family life are unrelated to expectations from the program.

The following table illustrates what the participants had expected from the CWT Program. 
TABLE IX

PARTICIPANTS' EXPECTATIONS OF THE PROGRAM

\begin{tabular}{|c|c|c|c|c|c|c|c|c|c|c|c|c|c|}
\hline & \multicolumn{2}{|c|}{ Material } & \multicolumn{2}{|c|}{ Training } & \multicolumn{2}{|c|}{ Job } & \multicolumn{2}{|c|}{ Residual } & \multicolumn{2}{|c|}{ None } & \multicolumn{2}{|c|}{$\begin{array}{c}\text { No } \\
\text { Response }\end{array}$} & \multirow[t]{2}{*}{ Total } \\
\hline & $\mathrm{H}$ & W & $\mathrm{H}$ & W & $\mathrm{H}$ & W & $\mathrm{H}$ & W & $\mathrm{H}$ & W & $\mathrm{H}$ & W** & \\
\hline C. $*$ & 4 & 6 & 3 & 2 & 12 & 9 & 2 & 2 & 1 & 3 & 0 & 0 & 44 \\
\hline M. * * & 17 & 14 & 14 & 16 & 6 & 3 & 2 & 4 & 3 & 3 & 0 & 0 & 82 \\
\hline Total & \multicolumn{2}{|c|}{41} & \multicolumn{2}{|c|}{35} & \multicolumn{2}{|c|}{30} & \multicolumn{2}{|c|}{10} & \multicolumn{2}{|c|}{10} & \multicolumn{2}{|c|}{0} & 126 \\
\hline$\%$ & \multicolumn{2}{|c|}{32.51} & \multicolumn{2}{|c|}{27.78} & \multicolumn{2}{|c|}{23.81} & \multicolumn{2}{|c|}{7.95} & \multicolumn{2}{|c|}{7.95} & \multicolumn{2}{|c|}{0.00} & 100 \\
\hline
\end{tabular}

$*$ C. = Clackamas County; M. = Marion County

$* * * \mathrm{H}$ and $\mathrm{W}$ indicates husband and wife.

Table $\mathrm{X}$ shows the degree to which the CWT Program met the expectations of the participants.

TABLE X

FULFILLMENT OF PARTICIPANTS' EXPECTATIONS

\begin{tabular}{cccccc}
\hline \multirow{2}{*}{$\begin{array}{c}\text { County } \\
\text { Clackamas }\end{array}$} & \multicolumn{3}{c}{ Yes } & \multicolumn{3}{c}{ No } \\
Masband Wife & Husband & Wife & Tota1 \\
$\begin{array}{c}\text { Motal } \\
\text { Total } \\
\text { Percent }\end{array}$ & 15 & 17 & 7 & 5 & 44 \\
& 18 & 14 & 20 & 24 & 76 \\
\hline
\end{tabular}


Examination of Table IX indicates that participants expected material benefits, vocational training, or just a temporary job in that order. Table XII illustrates that material expectations were not realized because some $51.27 \%$ of the frequencies indicated a decrease in standard of living as a result of CWT participation. Therefore, we conclude that expectations which did not materialize would not account for the positive changes in family life which were established.

Further examination of Table IX indicates vocational training or basic education as the second in importance in expectations. Generally we conclude that this expectation was not realized. Our reasoning is based on the following considerations:

(1) There was no significant difference between the "yes" and "no" categories indicated in Table X. The test of proportions, done on the difference between the percentages of the two categories, revealed that $P>.50$.

(2) The "yes" and "no" response categories refer to all three major classes of expectations. Further analysis of the data revealed that a large share of the frequencies under the "yes" category in Table X (Realization of Expectations) was provided by the population in Clackamas County. Since expectations of this sample ranked "a job" number one in importance, it seems evident that the high 
percentage of "yes" answers to fulfillment of expectations in Clackamas refers to job. In contrast, the Marion County population expected material benefits and training rather than "a job." Table $\mathrm{X}$ indicates that this expectation was not realized because only 32 of the 76 responses (42.11\%) reported that their expectations were met. The contrast between the two populations as related to expectations and realization of expectations is illustrated in Table $\mathrm{XI}$.

TABLE XI

REALIZATION OF EXPECTATIONS

\begin{tabular}{lccc}
\hline \hline County & Expectation & Realization \\
Clackamas & "A Job" & $72.72 \%$ & $27.28 \%$ \\
Marion & $\begin{array}{c}\text { "Material Gain } \\
\text { and Training" }\end{array}$ & $41.05 \%$ & $58.95 \%$ \\
\hline
\end{tabular}

The above data lead us to the conclusion that expectations which did not materialize did not contribute to the positive changes in family functioning already established. 
10. Positive changes in family functioning are unrelated to changes in the financial situation of the family.

This conclusion is supported by the analysis of the rejected null hypothesis $\mathrm{Ho}_{2}$ as related to $\mathrm{H}_{2}$ and Tables No. XII and XIII.

TABLE XII

CHANGES IN LEVEL OF LIVING DURING PARTICIPATION

\begin{tabular}{|c|c|c|c|c|c|c|c|}
\hline \multirow[b]{2}{*}{ County } & \multicolumn{2}{|c|}{ Increase } & \multicolumn{2}{|c|}{ Decrease } & \multicolumn{2}{|c|}{ Same } & \multirow[b]{2}{*}{ Total } \\
\hline & Husband & Wife & Husband & Wife & Husband & Wife & \\
\hline Clackamas & 6 & 4 & 11 & 11 & 5 & 7 & 44 \\
\hline Marion & 9 & 9 & 20 & 20 & 9 & 9 & 76 \\
\hline Total & \multicolumn{2}{|c|}{28} & \multicolumn{2}{|c|}{62} & \multicolumn{2}{|l|}{30} & 120 \\
\hline Percent & \multicolumn{2}{|c|}{23.95} & \multicolumn{2}{|c|}{51.27} & \multicolumn{2}{|c|}{24.78} & 100 \\
\hline
\end{tabular}

We conclude that the income available to families decreases in $51.27 \%$ of the cases during participation on $\mathrm{CWT}$. 
TABLE XIII

SPENDING PATTERN BEFORE AND AFTER PARTICIPATION

\begin{tabular}{|c|c|c|c|c|c|c|c|c|}
\hline & & $\begin{array}{l}\mathrm{ob}- \\
\text { lated }\end{array}$ & & $\begin{array}{l}\text { mily } \\
\text { lated }\end{array}$ & & ther & Dif & $\begin{array}{l}\text { No } \\
\text { erence }\end{array}$ \\
\hline & No. & $\%$ & No. & $\%$ & No. & $\%$ & No. & $\%$ \\
\hline $\begin{array}{l}\text { Participants } \\
\text { spend more } \\
\text { money on } \\
\text { these items }\end{array}$ & 69 & 49.64 & 5 & 3.60 & 9 & 6.48 & 56 & 40.28 \\
\hline $\begin{array}{l}\text { Participants } \\
\text { spend less } \\
\text { money on } \\
\text { these items }\end{array}$ & 10 & 8.00 & 55 & 44.58 & 14 & 11.21 & 45 & 36.21 \\
\hline
\end{tabular}

We conclude from the information in Table XIII that families spent disproportionately more money on job-related items during participation on the program than they did before. Since less money is available for family-related items during participation on the program a decrease in level of living results. This negative change does not reasonably account for the positive internal changes already established.

11. There are significant differences between Clackamas and Marion Counties in participants' perceptions of the CWT Program.

The differences in this respect are supported by the rejection of the null hypothesis relating to $\mathrm{H}_{6}$ and the analysis of Table XIV. 
TABLE XIV

MODAL RESPONSE CATEGORIES INDICATING DIFFERENCES IN REACTION TO PROGRAM, BY COUNTIES

\begin{tabular}{|c|c|c|c|}
\hline & Indices & Clackamas & Marion \\
\hline \multirow[t]{5}{*}{$\begin{array}{l}\text { Proglam } \\
\text { and Work: }\end{array}$} & Expectations & A job & $\begin{array}{l}\text { Material gain and } \\
\text { training }\end{array}$ \\
\hline & Realizations & Attained & Not attained \\
\hline & Positives & Job satisfaction & $\begin{array}{l}\text { Material and im- } \\
\text { proved functioning }\end{array}$ \\
\hline & Work & Work not preferred & Work preferred \\
\hline & Attitude & Negative & Positive \\
\hline \multirow[t]{4}{*}{ Service: } & $\begin{array}{l}\text { Frequency } \\
\text { of visit }\end{array}$ & Same & More \\
\hline & $\begin{array}{l}\text { Number of } \\
\text { home visits }\end{array}$ & Once a month & $\begin{array}{l}\text { Less than once a } \\
\text { month }\end{array}$ \\
\hline & $\begin{array}{l}\text { Number of } \\
\text { office visits }\end{array}$ & Once a month & $\begin{array}{l}\text { Less than once a } \\
\text { month }\end{array}$ \\
\hline & Time spent with & Husband & Wife \\
\hline
\end{tabular}

It should be noted here that, as a total population, participants in both counties expressed positive feelings tovard the program and, in overwhelming numbers, preferred to work while receiving as sistance. The differences between the two counties indicated in Table XIV refer to the differences in proportion. For example, we obtained a frequency of 68 preferring work, and 2 preferring not to work in Marion County. The ratio of frequencies was 35 preferring 
to work and 7 preferring not to work in Clackamas County.

No differences between the two counties' populations could be established in the following areas:

(1) In the identification of the CWT Program's negative as pects. Both populations clearly identified the lack of job satisfaction and the inadequate financial situation of the family as major problem areas relating to the program.

(2) The manner of money management within the family before and after participation on the CWT Program. The limitations of our questionnaire precluded adequate exploration of the possibility of role reversal during periods of unemployment.

(3) The amount of income available to the family during participation.

(4) Spending patterns before and during participation.

(5) Feelings about social work services in general.

(6) The participant's perception of the social worker's role and function.

Generally, we conclude that the differences between the counties in expectations, realizations, program and work preference, are significant in terms of responses of the participants. We speculate that these differences relate to the differences in administrative procedures, policies, orientation of the client to the 
program and the range of work opportunities provided.

\section{There are significant differences between the husbands' and}

wives' perceptions about various aspects of the program.

This conclusion is supported by the rejection of the null

hypothesis relating to $\mathrm{H}_{5}$. This was interpreted to mean that job satisfaction was the most important aspect of the CWT Program for men whether positive or negative. Material benefit, on the other hand, was the most important positive aspect for women. We speculate that this difference may be related to role expectations of the two sexes as well as to the difference in orientation to the program. No other significant differences were found.

\section{IMPLICATIONS}

The findings previously discussed appear to have some significant implications for those interested in program planning and administration. These implications can be viewed as related to the family, the program, and the relationship of the influence of one upon the other.

In examining family life we found that there is change which affects the family unit as a whole. We associate the positive changes reported by the families with the positive attitudes toward some aspects of the CWT Program. The aspects of the program identified 
as positive by the families are social work service, the opportunity to work, and the basic goals and purposes of the CWT Program with which they agree. This seems to imply that the provision of social work services on the whole is useful, should be provided at the present level of services, and that the caseworker's role is perceived as a contributing factor in improved functioning. The program itself seems to meet a need by providing work instead of only public as sistance. The findings in Clackamas County as well as a significant proportion of responses in Marion County tend to suggest that a work. program on a year-round basis might be useful in meeting the needs of either the seasonally unemployed or those whom society sees as unemployable because of present-day technological development.

Not only is work usually considered a significant aspect of the worker's identity, but the breadwinner's productive endeavor also has important implications for every member of the family unit. This is perhaps why such an overwhelming proportion of our responents preferred to work despite their perceptions of numerous negative aspects in the CWT Program.

In examining the CWT Program's negative aspects as reported by our respondents, we found that job satisfaction, expectations, and the families' financial situation appear to be major problem areas. In view of our findings related to the importance placed on job satisfaction, it would seem worthwhile if the variety of jobs could be 
enlarged and a way found to give individual recognition for work performed. It seems unfortunate that public assistance standards associated with this program are so low and compensation is not geared to individual performance but the work required appears to be an essential in job satisfaction.

The extremely low compensation also would tend to result in the families' social isolation which in turn might well defeat a basic purpose of the program. The participants' orientation to the program appears to be related to how they view effectiveness of the program. Participants in Marion County expected vocational training and material benefits, and did not think that their expectations were met. Unrealized expectations might conceivably produce dissatisfactions which would have an adverse effect on family life.

This study did not reveal what aspects of family life are affected by participation on the CWT Program as we treated the 14 indices of family functioning as if each were of equal importance and weight. We do not know how participants defined the term "helpful" in responding to our questionnaire. Furthermore, ourdata do not reveal the areas in which children's functioning is affected through the fathers' participation on the CWT Program.

A more appropriate research instrument will be required to explore the methodology, quality and quantity of social work services that are useful for participants in a CWT Program. 


\section{LIMITATIONS}

We have encountered a number of problems during the research process. These problems were related to the research design, the population, and the variables presented by the two administrative structures of Clackamas and Marion Counties. The problems and variables thus recognized have been carefully examined in order to determine the extent of their influence on our findings. In exsamining the research design it should be noted that the questionnaire was administered to a population that participated on the CWT Program some six months to three years prior to the interviews. Some of those who participated on the program for a short period of time between 1965 and 1967, and who had not been public assistance recipients for some time, did indicate some difficulty in recall. Also, the questionnaire was administered to a population that in many ways is representative of the culture of poverty, i. e., unable to verbalize feelings well because of educational limitations. In the sample population the educational level ranged from zero to ninth grade for $66.66 \%$, and grades ten to twelve for $33.34 \%$. None had education beyond high school.

Another problem area was that some of the respondents made either a total association or a total disassociation of public assistance and the CWT Program. We interviewed some people who 
worked on the program who considered it part of welfare and believed that there were no other assistance programs available to help them. On the other hand, we also interviewed people who believed that the program was only administratively related to the public welfare agency, that it was actually not connected with assistance and that they were therefore working for a wage. Apparently some of these participants return year after year to their winter job on the CWT Program. As an example, the cases in Clackamas County had been reopened an average of 5.5 times, and the cases in Marion County had been reopened an average of 2.8 times.

In examining the population further, we find significant demographic differences between Clackamas and Marion Counties. The population of Marion County included 93 Spanish-American families who represented $15.58 \%$ of the county's research population. There seemed to be no cultural minorities represented in the Clackamas County research population. We dealt with this problem by contrasting the perceptions of the two county populations and determining the differences by tests of significance. One should, however, be cautious in applying these conclusions on a wider basis because of the special population component in Marion County, as well as because of the variables presented by the differing administrative structures of the two counties studied.

In examining the counties' administrative structures through 
the responses of the participants as well as through official information from the agency itself, we found that there are two caseworkers assigned to all families in Clackamas County. One works with the husbands in relation to the work program, while the other works with the wife and children exclusively. In Marion County, on the other hand, caseworkers are assigned to work with the total family. This variable has been explored in terms of attitudes toward social work service and the attributes of each population contrasted.

\section{SUMMARY}

This study approached the examination of the CWT Program's effects on family life in terms of participants' attitudes toward the program, the meaning of work within this program, and the provision of social work services. These variables have been examined in terms of the time element, i. e., before and after participation, as well as from the viewpoint of treating the family as a system with both internal and external functions. The study revealed positive feelings toward the program itself as well as toward the components of work and social work service. This study also revealed some negative aspects of the program in the areas of the families' financial status, and working conditions on the jobs provided by the CWT Program. The study did not deal with one of the common assumptions about the program, that it prevents the stigma of unemployment. 
Important negative aspects mentioned by the participants in the program are the following. Job performance was poorly compensated, perhaps largely because of the limitation of resources available to the program; there was no choice for the participant in regard to working or not working and there was little or no choice of work assignment. The participant thus often felt he was not benefited because his capacities were not fitted to the job. It seems inevitable that this would adversely affect possible carry-over of experience to paid employment in another setting.

The findings of this study reinforced our initial impressions concerning the value of work in relation to the maintenance of man's identity. Therefore, we believe that the provision of the opportunity to work benefits the individual, his family as well as society. It follows that this opportunity should be provided for those temporarily unemployed. Our findings suggest that a work program administered by public agencies should consider the following guidelines:

1. Working conditions should approximate those in private industry as closely as possible.

a. Participants should be allowed to work a full 40 hours weekly.

b. Job tasks should be challenging, offer some variety, and be suited to individual capacities.

c. Personnel policies should be flexible in the areas of 
attendance, illness, and other personal problems such as transportation.

2. Incentives in the form of better compensation and individualized recognition are of great significance in a work program of this type.

3. Social work services may be utilized more effectively in terms of the following considerations:

a. Casework services should be available to all those who request it.

b. The caseworkers' function beyond the provision of services and information be clearly defined to all participants.

However, despite the changes that need to be made it is our impression that participation in the Community Work and Training Program was beneficial and that the most significant effect was the contribution it made to the maintenance of family life. 


\section{A SELECTED BIBLIOGRAPHY}

1. Anderson, Nels. Work and Leisure. New York: Free Press of Glencoe, Inc., A Division of Crowell-Collier Publishing Company, 1961.

2. Dimensions of Work: The Sociology of a Work Culture. McKay Social Science Series. New York:

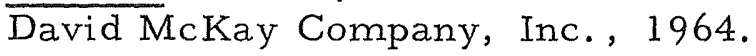

3. Becker, Joseph M., S. J., ed. In Aid of the Unemployed. Baltimore, Maryland: Johns Hopkins Press, 1965.

4. Bennett, Samuel V. Unemployment and Relief from the Local Government Point of View. A Report of W. E. Upjohn Institute for Community Research. Chicago: Public Administration Service, 1955.

5. Borow, Henry, ed. Man in a World at Work. Boston: Houghton Mifflin Company, 1964.

6. Charnow, John. Work Relief Experience in the United States. Pamphlet Series No. 8. Washington, D. C.: Washington Conference on Social Security, Social Science Research Council, February, 1943.

7. Colcord, Joanna C., assisted by Koplovitz, William C. and Kurtz, Russell. H. Emergency Work Relief as Carried Out in Twenty-Six American Communities, 1930-1931, With Suggestions for Setting up a Program. New York: Russell Sage Foundation, 1932.

8. Committee on Long-Range Work and Relief Policies. Report to the National Resources Planning Board. Security, Worle and Relief Policies, 1942. Washington: U. S. Government Printing Office, 1942 . 
9. Department of Commerce, Bureau of the Census, William J. Harris, Director. A Summary of State Laws Relating to the Dependent Classes, 1913. Washington: U.S. Government Printing Office, 1914.

10. de Schweinitz, Karl. England's Road to Social Security. A Perpetua Book. New York: A.S. Barnes and Company, Inc., 1943. Perpetua.Edition 1961.

11. Engel, George L., M. D. Psychological Development in Health and Disease. Philadelphia: W. B. Saunders Company, 1962 .

12. Feder, Leah Hannah, Ph. D. Unemployment Relief in Periods of Depression. A Study of Measures Adopted in Certain American Cities, 1857 through 1922. New York: Russell Sage Foundation, 1967.

13. Feldman, Frances Lomas and Scherz, Frances H. Family Social Welfare. Helping Troubled Families. New York: Atherton Press, 1967.

14. Freeman, Roger A. "Public Works and Work Relief." In Aid of the Unemployed. Edited by Joseph M. Becker, S.J. Baltimore, Maryland: Johns Hopkins Press, 1965.

15. Ginzberg, Eli, Ginsburg, Ethel L., Lynn, Dorothy L., Vickers, L. Mildred, and Ginsburg, Sol W., M. D. The Unemployed. I. Interpretation. II. Case Studies, New York: Harper and Brothers, Publishers, 1943.

16. Herzberg, Frederick, Mausner, Bernard, and Snyderman, Barbara Bloch. The Motivation to Work. New York: John Wiley and Sons, Inc., 1959.

17. MacIntyre, Duncan M. Public Assistance: Too Much or Too Little? The Dimensions of Poverty and Its Remedies. First in the Series. Bulletin 53-1. Ithaca, New York: New York School of Industrial and Labor Relations, Cornell University, December 1964.

18. Miller, Catherine M. and Ott, Olive B. in Department of Operations, Bureau of Family Services. "State Action on the Public Assistance Provisions of the 1962 Amendments." Welfare in Review, Vol. 1, No. 2 (August 1963) 1-15. 
19. Oregon State Public Welfare Commission. Staff Manual, Vol. II. Revised September 15, 1967. Sections 2416 and 2417.

20. Pumphrey, Ralph E. and Muriel W., ed. The Heritage of American Social Work. New York: Columbia University Press, 1961.

21. Radomski, Alexander Leopold. Work Relief in New York State, 1931-1935. Morning side Heights, New York: Kings Crown Press, 1947.

22. Sandoz, Carl Victor. "The Development of the Emergency Relief Program in Oregon, June, 1932 to January, 1936." Unpublished thesis submitted for the degree Master of Social Work, University of Washington, 1942.

23. Social Security Bulletin. October 1962. Vol. 25, No. 10 , "Public Welfare Amendments of 1962."

24. State Public Welfare Commission. A Report of Public Welfare in Oregon for the Fiscal Year July 1, 1959 - June 30, 1960. Salem, Oregon.

25. State Relief Committee. Biennial Report of State Relief Committee: to the Governor and Legislative Assembly of Oregon February 7, 1933 to December 31, 1934.

26. Therkildsen, Paul T. Public Assistance and American Values. Albuquerque, New Mexico: Division of Goverment Research, The University of New Mexico, 1964.

27. Towle, Charlotte. Common Human Needs. New York: National Association of Social Workers, Inc. , 1965.

28. U. S. Bureau of Family Services. Handbook of Public Assistance Administration. Part IV, dated February 7, 1963. As transmitted by State Letter No. 623.

29. United States Department of Labor. Manpower Report of the President and A Report on Manpower Requirements, Re. sources, Utilization and Training by the United States Department of Labor. Transmitted to the Congress, March, 1965. 
30. Wilcock, Richard C, and Franke, Walter H. Unwanted Workers. New York: Free Press of Glencoe, Division of MacMillan Company, 1963.

31. Wilensky, Harold L. "Varieties of Work Experience." Man in a World at Work. Edited by Henry Borow. Boston: Houghton Mifflin Company, 1964.

32. Williams, Edward Ainsworth. "Federal Aid For Relief." Doctoral Dissertation. Columbia University.

Columbia University Press, 1939.

33. Wrenn, C. Gilbert. "Human Values and Work in American Life." Man in a World at Work. Edited by Henry Borow. Boston: Houghton Mifflin Company, 1964. 


\title{
APPENDIX
}

\author{
QUESTIONNAIRE USED IN THE STUDY
}

\section{FACE SHEET OF QUESTIONNAIRE}

Interviewer:

Date of interview:

Case Number:

County:

Residence:

Rural: Urban:

Suburban:

Persons interviewed:

Husband:

Wife:

Age:

Husband:

Wife:

Number of children:

Education:

Husband:

Wife:

Place of birth:

Husband:

Wife:

Nationality:

Spanish American:

Other:

Migrant/Non-migrant:

Year worked:

Began program:

Ended program:

First time on public assistance:

Number of times reopened:

Presently on work program: Distance to work:

Level of family functioning (SPW 505): 


\section{Body of Questionnaire}

1. What did you expect to get from the work program?

2. Are you getting what you expected from the work program?

3. Will you tell me three good things about the work program?

4. What has helped your family the most?

5. What else is good about the work program?

6. Will you tell me three things that are not good about the work program?

7. What has caused the biggest problem for your family?

8. What else is not good?

9. Would you rate the following as to how they've been affected since you started the work program? Please choose from the following: (1) much worse; (2) little worse; (3) the same; (4) little better; (5) much better.

a. Your children's grades in school,

b. Your children's behavior

c. Getting along with each other

d. Getting along with neighbors

e. Feelings about the family.

f. Feelings about work.

g. Work habits

h. Housing. 
i. Earnings

j. Food you eat

k. Things you own.

1. Places you can go.

m. Health

n. Going to church.

10. Who decided how the money in your family was to be spent before you started the work program?

11. Who decides how the money is to be spent now?

12. What are the things you spent more money for while on the work program as compared with being off the work program?

13. What are the things you spent less money for while on the work program as compared with being off the work program?

14. Has the amount of money while on the work program increased; is it less; the same?

15. How often has your caseworker been helpful to you?
a. Rarely or never
d. Often
b. Seldom
e. Very often
c. Sometimes

16. Would you like to see your caseworker:
a. Not at all
c. Less often
b. About the same.
d. More often 
17a. While on the work program, how often have you seen your caseworker at home?

1. Less than once a month.

2. Once a month.

3. More than once a month

17b. While on the work program, how often have you seen your caseworker at the welfare office?

1. Less than once a month

2. Once a month.

3. More than once a month.

17c. What kind of help does the caseworker offer? (If just talk, what do you talk about?)

17d. Does your caseworker spend more time with your husband/wife; your children? Who gets the next largest amount of time? The least?

18. If you had your choice of the work program or receiving public assistance without work, which would you choose? Why?

19. What other good or bad things are there we might have forgotten to mention?

20. When we publish this report, what else is there you would like people to know? 